
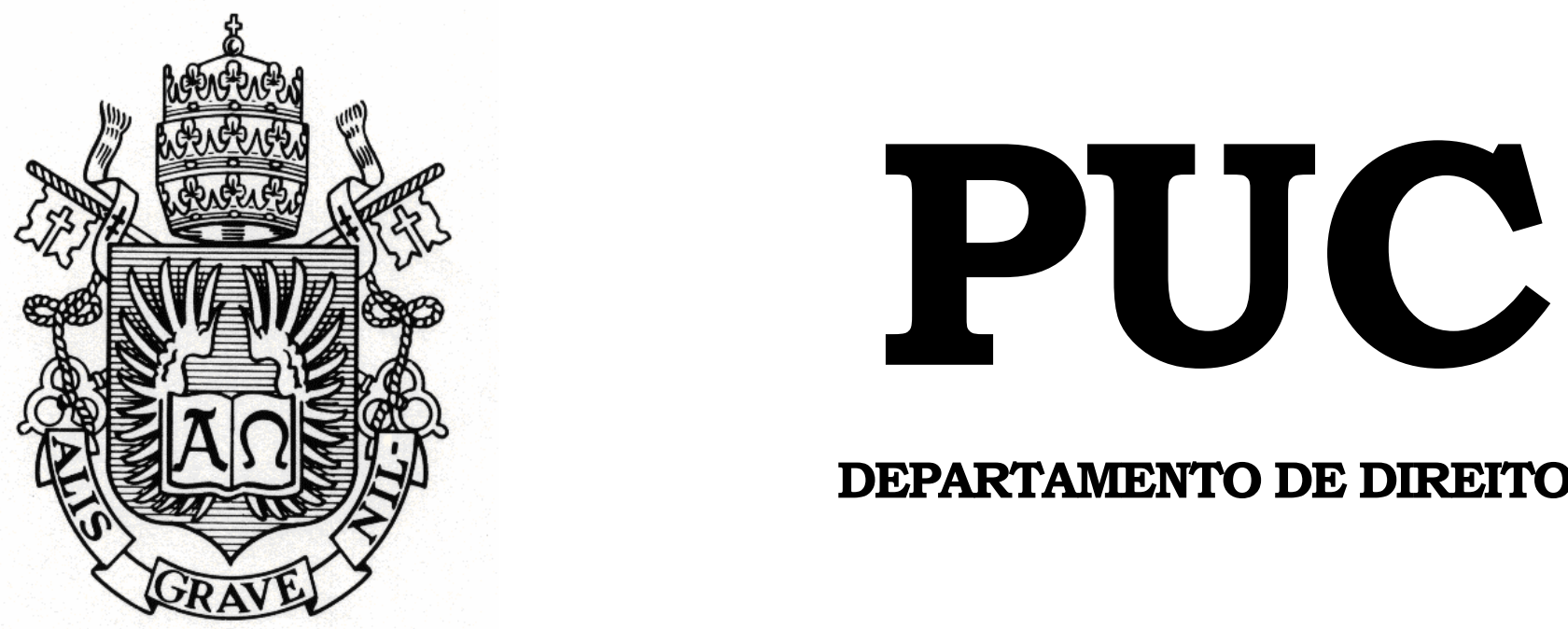

DEPARTAMENTO DE DIREITO

\title{
O DIREITO DOS ÍNDIOS AO RECONHECIMENTO DE SUAS TERRAS E O LICENCIAMENTO AMBIENTAL
}

por

FERNANDA MIRALDES BULUS

ORIENTADOR(A): DANIELLE DE ANDRADE MOREIRA 2010.2

PONTIFÍCIA UNIVERSIDADE CATÓLICA DO RIO DE JANEIRO

RUA MARQUÊS DE SÃO VICENTE, 225 - CEP 22453-900 RIO DE JANEIRO - BRASIL 


\section{O DIRETTO DOS ÍNDIOS AO RECONHECIMENTO DE}

\section{SUAS TERRAS E O LICENCIAMENTO AMBIENTAL}

por

FERNANDA MIRALDES BULUS

Monografia apresentada ao Departamento de Direito da Pontificia Universidade Católica do Rio de Janeiro (PUC-Rio) para a obtenção do Título de Bacharel em Direito.

Orientador(a): Danielle de Andrade Moreira 
Resumo: A presente monografia tem como escopo analisar o direito dos índios ao reconhecimento de suas terras a fim de identificar como se dá o licenciamento ambiental de atividades efetiva ou potencialmente poluidoras, que possam gerar eventuais impactos em terras indígenas. Para tanto, partiu-se do histórico da evolução legislativa acerca do direito conferido aos índios, desde o período colonial até o advento da Constituição Federal de 1988, que consagrou o reconhecimento aos índios dos direitos originários sobre as terras que tradicionalmente ocupam, impondo à União o dever de demarcá-las e protegê-las. Cada capítulo do presente estudo expõe as principais questões suscitadas pela doutrina e pela jurisprudência.

Palavras-chave. Demarcação, Impactos, Índios, Licenciamento Ambiental, Terras Indígenas. 


\section{SUMÁRIO}

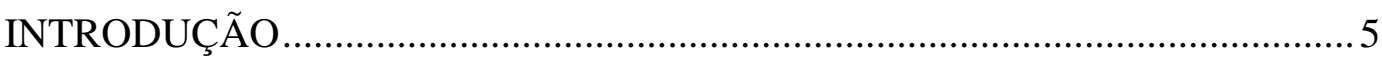

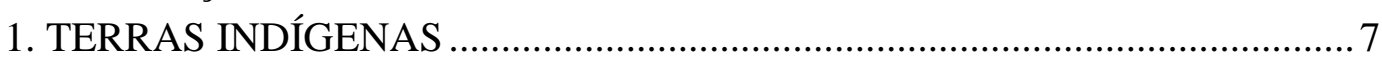

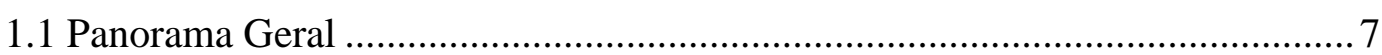

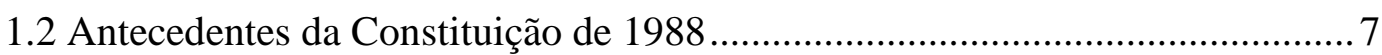

1.2.1 Legislação Colonial e Brasileira................................................................... 7

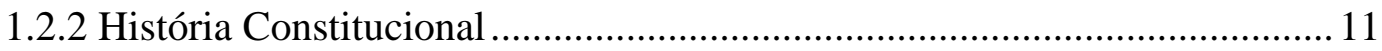

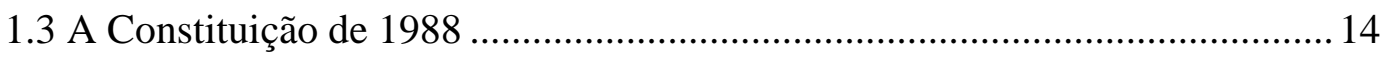

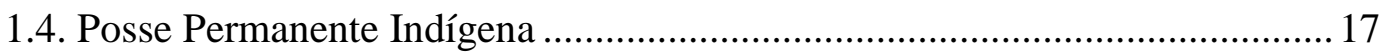

1.5. Requisitos Para o Reconhecimento de uma Comunidade Indígena -

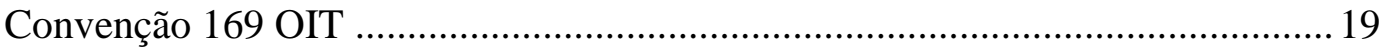

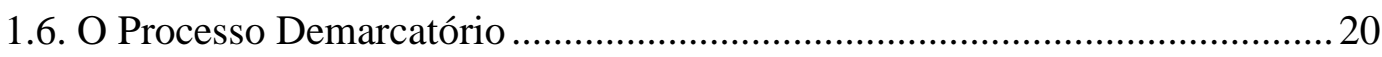

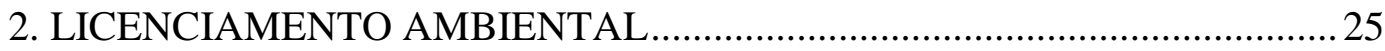



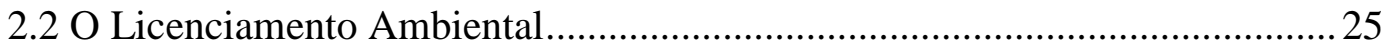

2.2.1 Um Instrumento de Controle Prévio........................................................ 25

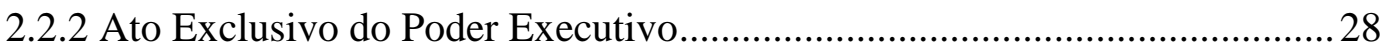

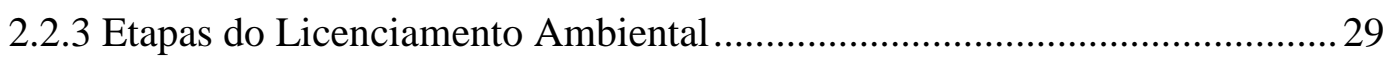

2.2.4 Competências para Realização do Licenciamento Ambiental ...................... 31

2.3 O Estudo de Impacto Ambiental e seu Respectivo Relatório de Impacto

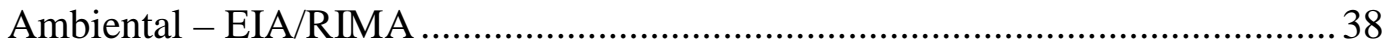

3. O COMPONENTE INDÍGENA NO LICENCIAMENTO AMBIENTAL ...... 43

3.1 O Papel da Funai no Licenciamento Ambiental............................................. 43

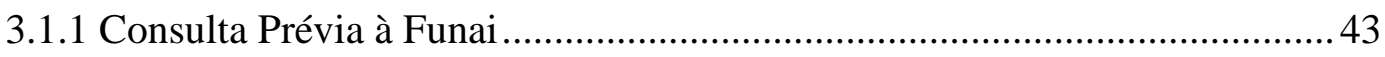

3.1.2 FUNAI: Órgão Integrante do SISNAMA...................................................... 45

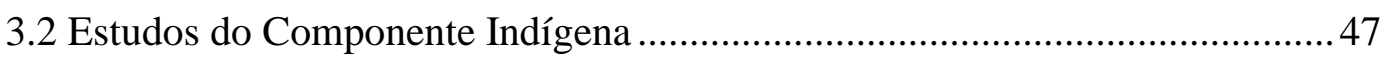

3.2.1 Parte Integrante do Diagnóstico Socioeconômico......................................... 47

3.2.2 Ausência de Legislação Específica............................................................ 48

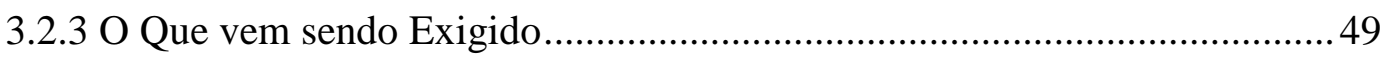

3.3 Licenciamento de Empreendimentos com Impactos em Terras Indígenas ..................52

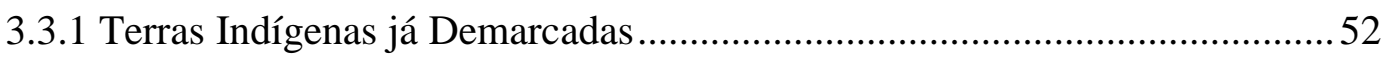

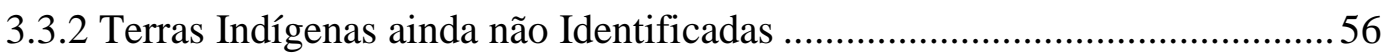

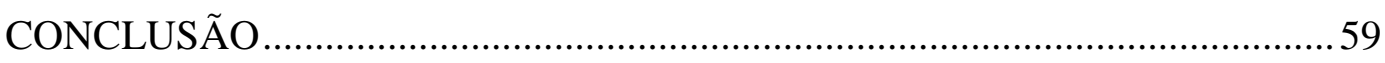

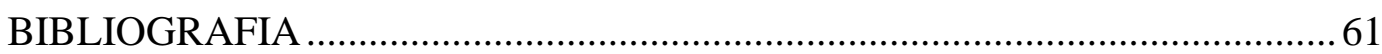




\section{Lista de abreviações e símbolos}

ADCT: Ato das Disposições Constitucionais Transitórias

AMS: Apelação em Mandado de Segurança

Art.: Artigo

CF: Constituição da República Federativa do Brasil de 1988

CNPI: Comissão Nacional de Política Indigenista

CONAMA: Conselho Nacional do Meio Ambiente

EIA/RIMA: Estudo de Impacto Ambiental e seu respectivo Relatório de Impacto Ambiental

FUNAI: Fundação Nacional do Índio

IBAMA: Instituto Brasileiro do Meio Ambiente e dos Recursos Naturais

Renováveis

MPF: Ministério Público Federal

MS: Mandado de Segurança

OIT: Organização Internacional do Trabalho

PL: Projeto de Lei

SISNAMA: Sistema Nacional do Meio Ambiente

STF: Supremo Tribunal Federal

TRF: Tribunal Regional Federal

§: Parágrafo

$\mathrm{N}^{\mathrm{o}}$ : Número 


\section{INTRODUÇÃO}

O presente estudo pretende analisar o direito dos índios ao reconhecimento de suas terras, de forma a entender como se dá o procedimento de licenciamento ambiental de atividades efetivas ou potencialmente poluidoras que possam ocasionar, de alguma forma, impactos em terras indígenas ou em seu entorno, ante a ausência de legislação específica sobre o tema.

A existência das terras indígenas já era reconhecida pelo ordenamento jurídico brasileiro, desde a época colonial. Contudo, foi na Constituição de 1988 que restou consagrado o reconhecimento aos índios dos direitos originários sobre as terras que tradicionalmente ocupam.

Assim sendo, a Constituição determinou ser competência da União Federal a demarcação das terras indígenas, bem como proteger e fazer respeitar os bens nelas existentes.

Nota-se a intenção do legislador constituinte de compensar as desvantagens históricas em relação aos índios, primeiros e naturais donos de suas terras, permitindo que eles desfrutem de um espaço fundiário que lhes assegure meios de sobrevivência física e cultural, em razão da íntima relação existente entre os índios e suas terras.

Neste sentido, as terras indígenas foram consideradas como inalienáveis, imprescritíveis e indisponíveis, de forma a garantir sua proteção e aos direitos dos índios sobre elas. Desta forma, lhes foi concedido o usufruto exclusivo dos recursos naturais nelas existentes.

O direito dos índios de habitar suas terras e delas usufruir é anterior ao reconhecimento formal pelo Poder Público, entretanto, o procedimento demarcatório das terras indígenas é indispensável para a produção dos efeitos fáticos e jurídicos dela decorrentes.

Por outro lado, é de conhecimento de todos que a localização geográfica dos povos indígenas desperta o interesse econômico de diversos empreendedores, principalmente daqueles que atuam no ramo de mineração 
e extração de produtos naturais, bem como na geração de energia elétrica por meio da construção de usinas hidrelétricas.

Como sabido, o desenvolvimento de atividades passíveis de causar impactos ao meio ambiente devem ser precedidas de licenciamento ambiental perante o órgão ambiental competente, o qual, no âmbito de sua competência, determinará as limitações e exigências a serem cumpridas para a instalação das referidas atividades.

Neste contexto, a presente monografia estudará os principais aspectos dos pontos acima mencionados, com o intuito de entender melhor o procedimento de licenciamento ambiental de empreendimentos e atividades que possam causar impactos em terras indígenas. 


\section{TERRAS INDÍGENAS}

\subsection{Panorama Geral}

A inclusão de um capítulo constitucional dedicado exclusivamente aos índios e seus direitos demonstra não só a relevância da matéria, como também a evolução da proteção conferida aos indígenas no ordenamento jurídico brasileiro.

Dentre os direitos conferidos aos indígenas, o reconhecimento do direito dos índios às terras que tradicionalmente ocupam é, sem dúvida, o tema mais importante dentro do Direito Indigenista.

Diante disso, passemos a analisar o direito garantido constitucionalmente aos indígenas de reconhecimento às suas terras, desde suas origens na legislação colonial, bem como o procedimento demarcatório destas.

\subsection{Antecedentes da Constituição de 1988}

\subsubsection{Legislação Colonial e Brasileira}

Antes de qualquer previsão constitucional acerca da questão indígena, a legislação colonial já reconhecia a existência de terras indígenas, conforme se depreende da leitura do Parecer de autoria do Dr. Luiz Fernando Villares e Silva ${ }^{1}$, Procurador Geral da Fundação Nacional do Índio - FUNAI, ao analisar o reconhecimento da Terra Indígena Potiguara de Monte-Mór, do qual são extraídas as seguintes passagens:

\footnotetext{
1 Informação $N^{\circ}$ 285/PGF/PG/FUNAI/2005. Processo $N^{\circ}$ 08620.1821/2000 (02 Vol.) Interessados: grupo indígena potiguara. Assunto: identificação e delimitação da terra indígena potiguara de Monte-Mór. Disponível em <http://www.funai.gov.br/procuradoria/docs/ Parecer\%20TI\%20Potigura\%20Monte-Mor.doc>. Acesso em 23 ago. 2010.
} 
O reconhecimento do direito dos índios às terras que tradicionalmente ocupam é agasalhado pelo ordenamento jurídico brasileiro. Segundo nos ensina PAULO DE BESSA ANTUNES, já no início do século XVII, verifica-se a existência de legislação colonial reconhecendo a existência de terras indígenas, ou seja, terras destinadas à posse e ao domínio exclusivamente de indígenas.

Nesse sentido, as disposições da Carta Régia de 30 de julho de 1609, bem como as de 10 de setembro de 1611, expedidas por Filipe III, que reconheciam o pleno domínio dos índios sobre seus territórios e sobre as terras que lhes são alocadas nos aldeamentos': "... os gentios são senhores de suas fazendas nas povoações, como o são na Serra, sem lhes poderem ser tomadas, nem sobre ellas se lhes fazer molestia ou injustiça alguma; nem poderão ser mudados contra suas vontades das capitanias e lugares que lhes forem ordenados, salvo quando elles livremente o quizerem fazer..." (Carta Régia, 10.9.1611).

Ainda mais explícito é o Alvará de $1^{\circ}$ de abril de 1680, que declara que as sesmarias concedidas pela Coroa Portuguesa não podiam afetar os direitos originais dos índios sobre suas terras. "Primários e naturais senhores" de suas terras eram enquanto tais isentos de qualquer foro ou tributo sobre elas: "... E para que os ditos Gentios, que assim descerem, e os mais, que há de presente, melhor se conservem nas Aldeas: hey por bem que senhores de suas fazendas, como o são no Sertão, sem lhe poderem ser tomadas, nem sobre ellas se lhe fazer molestia. E o Governador com parecer dos ditos Religiosos assinara aos que descerem do Sertão, lugares convenientes para neles lavrarem, e cultivarem, e não poderão ser mudados dos ditos lugares contra sua vontade, nem serão obrigados a pagar foro, ou tributo algum das ditas terras, que ainda estejão dadas em Sesmarias e pessoas particulares, porque na concessão destas se reserva sempre o prejuízo de terceiro, e muito mais se entende, e quero se entenda ser reservado o prejuízo, e direito os Índios, primários e naturaes senhores dellas..." (Alvará de 1.4.1680, parágrafo 4). Proibiu-se, explicitamente, que fossem retirados destas terras sem seu consentimento; e, isentou-os do pagamento de fôro ou tributo pela ocupação de suas terras. Em que pese destinado inicialmente ao tratamento das questões relativas aos povos indígenas do Grão-Pará e Maranhão, as disposições do Alvará de 1680 foram estendidas, posteriormente, por obra do Alvará de 8 de maio de 1758, para todo o Brasil ${ }^{3}$. Razão pela qual é considerado um marco legislativo no que tange aos problemas indigenistas em geral ${ }^{4}$.

Por obra deste Alvará teria surgido o indigenato, que, segundo JOSÉ AFONSO DA SILVA, é uma "velha e tradicional instituição jurídica luso-brasileira que deita suas raízes já nos primeiros tempos da Colônia, quando o Alvará de $1^{\circ}$ de abril de 1680, confirmado pela Lei de 6 de junho de 1755, firmara o princípio de que, nas terras outorgadas a particulares, seria sempre reservado o direito dos índios, primários e naturais senhores delas"5. Instituto que pode ser definido como uma fonte primária, originária, congênita, de posse territorial por parte dos índios, que "tinham o domínio por título legítimo - indigenato, que não é o direito adquirido, mas congênito, primeiro. Logo, as suas posses não estavam sujeitas à legitimação"6.

2 ANTUNES, Paulo de Bessa. Ação Civil Pública, Meio Ambiente e Terras Indígenas. Rio de Janeiro: Lumen Juris, 1998. p. 173.

3 TOURINHO NETO, Fernando da Costa. "Os direitos originários dos índios sobre as terras que ocupam e suas conseqüências jurídicas", in SANTILLI, Juliana. Os direitos indígenas e a Constituição. Porto Alegre: NDI e Fabris, 1993. p. 9/10.

4 ANTUNES, Paulo de Bessa. Ação Civil Pública, Meio Ambiente e Terras Indígenas. Rio de Janeiro: Lumen Juris, 1998. p. 173.

5 SILVA, José Afonso da. Curso de Direito Constitucional Positivo. São Paulo: Malheiros,

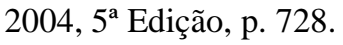

6 TOURINHO NETO, Fernando da Costa. Op. cit. p. 13. 
Contudo, embora a Coroa Portuguesa demonstrasse uma certa prodigalidade na edição de atos protetores do direito indígena, na prática este direito não era efetivado. Especialmente no que tange ao reconhecimento do direito dos silvícolas às suas terras. Exemplo disso era a possibilidade, prevista na Lei de 10 de março de 1570, de escravizar os índios quando "tomados em guerra justa autorisada pelo rei ou governadores, ou nas correrias matutinas em que assaltavam e roubavam as habitações, assassinando seus habitantes, ou quando matassem os inimigos para os comer" ${ }^{7}$. Situação esta que, além de privar os silvícolas de sua liberdade, acabou privando-os de suas terras, pois com a edição da Carta Régia de 2 de dezembro de 1808, Dom João VI declarou devolutas as terras conquistadas aos índios a quem havia sido declarada guerra justa ${ }^{8}$.

Entretanto, se por um lado a Carta Régia de 2 de dezembro de 1808 prejudicou aqueles que perderam suas terras por "guerra justa", por outro reconheceu que as terras ocupadas por silvícolas não são naturalmente devolutas, devendo existir um ato normativo a extinguir-lhes o domínio - como a malfadada Carta Régia de 1808 - que neste sentido disponha.

Como transcrito acima, o Alvará de 1680 - que passou a surtir efeitos para todo o Brasil após o Alvará de 8 de maio de 1758 - reconheceu que os povos indígenas foram os primeiros e naturais donos de suas terras, não devendo pagar, portanto, nenhum tributo sobre elas. Referido Alvará determinou, ainda, que os silvícolas não poderiam ser retirados de suas terras sem seu consentimento.

Diante disso, conclui-se que as terras de posse indígena não podiam ser consideradas devolutas, eis que pertenciam aos índios por título congênito, independentemente de legitimação.

Em 1850 foi promulgada a Lei de Terras (Lei n. 601, de 18/9/1850), a qual regulou o regime fundiário no País. Mencionada lei determinou que as terras devolutas, isto é, as que não estavam aplicadas a algum uso público nacional, estadual ou municipal bem como aquelas que não estavam no domínio particular em virtude de título legítimo ${ }^{9}$, fossem destinadas,

7 TOURINHO NETO, Fernando da Costa. Op. Cit. p. 12.

8 CUNHA, Manuela Carneiro da (org.). Legislação indigenista no Século XIX: Uma compilação: 1808-1889. São Paulo: EDUSP: Comissão Pró-Índio de São Paulo, 1992. p. 15.

9 De acordo com o artigo terceiro da Lei de Terras, eram devolutas as terras nas seguintes condições: "Art. $3^{\circ}$ São terras devolutas: $\S 1^{\circ}$ As que não se acharem applicadas a algum uso publico nacional, provincial, ou municipal. $\S 2^{\circ}$ As que não se acharem no domínio particular por qualquer titulo legitimo, nem forem havidas por sesmarias e outras concessões do Governo Geral ou Provincial, não incursas em comisso por falta do cumprimento das condições de medição, confirmação e cultura. $\S 3^{\circ}$ As que não se acharem dadas por sesmarias, ou outras concessões do Governo, que, apezar de incursas em com isso, forem revalidadas por esta Lei. § $4^{\circ}$ As que não se acharem occupadas por posses, que, apezar de não se fundarem em titulo legal, forem legitimadas por esta Lei". 
dentre outras coisas, "à colonização dos indígenas" (art.12) ${ }^{10}$. Logo, nota-se, mais uma vez, que as terras de posse indígena eram públicas, desde sempre.

Com efeito, inexistia, na nova legislação, qualquer referência ao direito originário indígena sobre os territórios que tradicionalmente ocupavam, ou seja, sobre o "indigenato". José Mauro Gagliardi avaliou que, com a nova lei, "(...) o indígena passou da condição de proprietário natural da terra à condição de expropriado e a depender da benevolência do Estado para ter algo que um dia lhe pertenceu"11.

Na República, em 1911, por meio do Decreto n 9.214, de 15 de dezembro, ficou estabelecido que o Serviço de Proteção aos Índios (S.P.I.) deveria prestar "assistência aos índios no Brazil que viviam aldeados, reunidos em tribus, em estado nômade ou promiscuamente com civilizados". A mesma norma determinava que competia à autoridade "garantir a efetividade da posse dos territórios ocupados por índios", ao mesmo tempo em que proibia a prática de qualquer ato que tivesse por objetivo transacionar tais terras, sob pena de nulidade ${ }^{12 e 13}$. Já em 1911 preocupava-se a administração com a restituição aos indígenas dos terrenos que lhes tivessem sido "usurpados". Até mesmo o "usufruto indígena" já encontrava previsão legal ${ }^{14}$, quando discriminadas e demarcadas as áreas nas quais os indígenas detivessem a posse.

Ainda que a linguagem adotada à época da edição do decreto $\mathrm{n}^{\mathrm{o}}$ 9.214/1911 tenha adquirido significado diverso nos dias de hoje,

10 "Art. 12. O Governo reservará das terras devolutas as que julgar necessarias: $1^{\circ}$, para a colonisação dos indígenas..."

11 Apud. MENDES JUNIOR, João. Os indígenas do Brazil, seus direitos, individuais e políticos. São Paulo: Typ. Hennies Irmãos, 1921, p.32.

12 "Art. $2^{\circ}$ A assistencia de que trata o art. $1^{\circ}$ terá por objecto: ........... $2^{\circ}$, garantir a effectividade da posse dos territorios occupados por indios e, conjunctamente, de que nelles se contiver, entrando em acordo com os governos locaes, sempre que fôr necessario;..............12, promover, sempre que fôr possivel, e pelos meios permittidos em direito a restituição dos terrenos que lhes tenham sido usurpados."

13 "Art. $7^{\circ}$ Os índios não poderão arrendar, alienar ou gravar com onus reaes as terras que lhes forem entregues pelo Governo Federal. Art. $8^{\circ}$ Os contractos dessa natureza, que forem realizados pelos mesmos, serão considerados nullos de pleno direito".

14 "Art. $6^{\circ}$ Satisfeito o disposto nos artigos anteriores, o governo providenciará para que seja garantido aos índios o usufructo dos terrenos demarcados". 
reconheciam-se direitos aos índios que viviam "em promiscuidade" com os brancos. O sentido do termo "promiscuidade", no contexto da época, era o de índios que conviviam com os "brancos".

\subsubsection{História Constitucional}

A primeira Constituição Brasileira a tratar expressamente da matéria relativa aos direitos dos indígenas foi a Constituição de 1934, que acabou por consolidar o reconhecimento constitucional da posse indígena. Em seu artigo $5^{\circ}$, ficou estabelecida a competência da União para promover a interação dos aborígenes à comunidade nacional (artigo $5^{\circ}, \mathrm{XIX}, \mathrm{m}^{15}$ ). Além disso, a Carta de 1934 determinou que fosse respeitada a posse dos indígenas (silvícolas no Texto de então) sobre as terras que ocupassem permanentemente, sendo vedada a alienação (art. 129) ${ }^{16}$.

Pontes de Miranda comentou o artigo 129 da seguinte forma:

... respeita-se a "posse" do silvícola, posse a que ainda se exige a localização permanente.... Desde que há a posse e a localização permanente, a terra é do nativo, porque assim o quis a Constituição, e qualquer alienação de terras por parte de silvícolas, ou em ${ }_{17}$ que se achem permanentemente localizados e com posse os silvícolas, é nula.

A própria "Constituição de 1937", a qual consistiu numa verdadeira Carta Ditatorial, também reconheceu a posse dos "silvícolas" sobre as terras que ocupavam em caráter permanente $e^{18}$.

Por sua vez, a Constituição de 1946, que consolidou o fim do período ditatorial e, consequentemente, o retorno da democracia, também tratou da matéria, mantendo a competência privativa da União para legislar

15 "Art $5^{\circ}$ - Compete privativamente à União: XIX - legislar sobre: m) incorporação dos silvícolas à comunhão nacional".

16 "Art 129 - Será respeitada a posse de terras de silvícolas que nelas se achem. permanentemente localizados, sendo-lhes, no entanto, vedado aliená-las."

17 MIRANDA, Pontes de. Comentários à Constituição da República dos Estados Unidos do Brasil. Rio de Janeiro: Editora Guanabara Waissmann, Koogan, Ltda. Tomo II. p. 348.

18 "Art 154 - Será respeitada aos silvícolas a posse das terras em que se achem localizados em caráter permanente, sendo-lhes, porém, vedada a alienação das mesmas". 
sobre a incorporação dos silvícolas à comunidade nacional $\left(\operatorname{art} .5^{\circ}, \mathrm{XV}, \mathrm{r}^{19}\right)$

e persistindo no respeito à posse das terras que ocupassem permanentemente (art. 216) ${ }^{20}$.

No que se refere à interpretação do artigo 216 da Carta de 1946, o Supremo Tribunal Federal, por voto do Ministro Vitor Nunes Leal, examinou a questão em profundidade no Recurso Extraordinário nº 44.585, cuja transcrição se passa a fazer:

Aqui não se trata do direito de propriedade comum; o que se reservou foi o território dos índios. Essa área foi transformada num parque indígena, sob a guarda e administração do Serviço de Proteção aos Índios, pois estes não têm disponibilidade de terras. O objetivo da Constituição Federal é que ali permanecem os traços culturais dos antigos habitantes, não só para a sobrevivência dessa tribo, como para estudo dos etnólogos e para outros efeitos de natureza cultural ou intelectual. Não está em jogo, propriamente, um conceito de posse, nem de domínio, no sentido civilista dos vocábulos; trata-se do habitat de um povo. Se os índios, na data da Constituição Federal, ocupavam determinado território, porque desse território tiravam seus recursos alimentícios, embora sem terem construções ou obras permanentes que testemunhassem posse de acordo com o nosso conceito, essa área, na qual e da qual viviam, era necessária à sua subsistência. Essa área, existente na data da Constituição Federal, é que se mandou respeitar. Se ela foi reduzida por lei posterior; se o Estado a diminuiu de dez mil hectares, amanhã a reduzirá em outros dez, depois mais dez, e poderia acabar confinando os índios a um pequeno trato, até o território da aldeia, porque ali é que a 'posse' estaria materializada nas malocas. ${ }^{21}$

Em sede doutrinária, Pontes de Miranda assim comentou o referido dispositivo:

O texto respeita a 'posse' do silvícola, posse a que ainda se exige o pressuposto da localização permanente. O juiz que conhecer de alguma questão de terras deve aplicar o art. 216, desde que os pressupostos estejam provados pelos silvícolas, ou constem dos autos, ainda que algumas das partes ou terceiro exiba título de domínio. Desde que há posse e a localização permanente, a terra é do nativo, porque assim o diz a Constituição, e qualquer alienação de terras por parte de silvícolas, ou em que se achem permanentemente localizados e com posse, os silvícolas, é nula, por infração da Constituição. Aquelas mesmas que forem em

19 "Art. 50 - Compete à União: XV - legislar sobre: r) incorporação dos silvícolas à comunhão nacional".

20 "Art. 216 - Será respeitada aos silvícolas a posse das terras onde se achem permanentemente localizados, com a condição de não a transferirem".

21 STF, RE 44.585, Rel. Ministro Ribeiro da Costa, Brasília, 30 ago. 1961. Disponível em <http://www.stf.jus.br/portal/geral/verPdfPaginado.asp?id=144244\&tipo=AC\&descricao=Inteiro \%20Teor\%20RE\%20/\%2044585>. Acesso em 15 ago 2010. 
virtude do art. 216 reconhecidas como de posse de tais gentes, não podem se alienadas. Os juízes não podem expedir mandados contra silvícolas que tenham posse, e nas terras, de que se trata, se localizaram com permanência. A proibição de alienação tem como conseqüências: a) a nulidade de qualquer ato de disposição incluídos aqueles que só se referem a elementos do direito de propriedade ou da posse (usufruto, garantia real, locação); b) não há usucapião contra silvícola ainda que trintenal; c) as sentenças que adjudiquem tais terras a outrem são suscetíveis de rescisão, dentro do prazo de preclusão, por infringirem texto constitucional. ${ }^{22}$

Já a Constituição de 1967 ampliou o rol de competências da União, incluindo a de legislar sobre nacionalidade, cidadania e naturalização; incorporação dos silvícolas à comunhão nacional (Art. $8^{\circ}, \mathrm{XVII}, \mathrm{o}^{23}$ ). Além disso, manteve o reconhecimento da posse das terras ocupadas em caráter permanente pelos silvícolas, outorgando-lhes, ainda, o usufruto permanente dos recursos naturais e das utilidades nelas existentes (art. $186^{24}$ ), o que acarretou no reconhecimento de que as terras ocupadas pelos silvícolas eram de propriedade da União (art. $4^{\mathrm{o}}, \mathrm{IV}^{25}$ ).

A Emenda Constitucional $\mathrm{n}^{\circ} 1$, de 17 de outubro de 1969, outorgada à Nação por força do Ato Institucional $n^{\circ} 5$, foi a que dedicou maior espaço à matéria. Manteve a tradição de reconhecimento da posse dos indígenas em relação às terras por eles ocupadas e, sob pressão internacional, declarou nulos e extintos todos os atos jurídicos que tivessem por objeto a posse, o domínio ou a mera ocupação das terras habitadas pelos silvícolas (art. 198. $\S \S 1^{\mathrm{o}}$ e $2^{\mathrm{o} 26}$ ). Ficou estabelecido, ainda, que tal declaração de nulidade não daria ensejo a qualquer indenização. É importante destacar que as terras

\footnotetext{
22 MIRANDA, Pontes de. Comentários à Constituição de 1946, vol. V, 1953, p. 335-336.

23 "Art $8^{\circ}$ - Compete à União: XVII - legislar sobre: o) nacionalidade, cidadania e naturalização; incorporação dos silvícolas à comunhão nacional".

24 "Art 186 - É assegurada aos silvícolas a posse permanente das terras que habitam e reconhecido o seu direito ao usufruto exclusivo dos recursos naturais e de todas as utilidades nelas existentes".

25 "Art $4^{\circ}$ - Incluem-se entre os bens da União: IV - as terras ocupadas pelos silvícolas".

26 "Art. 198. As terras habitadas pelos silvícolas são inalienáveis nos têrmos que a lei federal determinar, a êles cabendo a sua posse permanente e ficando reconhecido o seu direito ao usufruto exclusivo das riquezas naturais e de tôdas as utilidades nelas existentes. $\S 1^{\circ}$ Ficam declaradas a nulidade e a extinção dos efeitos jurídicos de qualquer natureza que tenham por objeto o domínio, a posse ou a ocupação de terras habitadas pelos silvícolas. $\$ 2^{\circ}$ A nulidade e extinção de que trata o parágrafo anterior não dão aos ocupantes direito a qualquer ação ou indenização contra a União e a Fundação Nacional do Índio."
} 
ocupadas pelos indígenas continuaram guardando a natureza jurídica de terras públicas federais ${ }^{27}$.

Diante do histórico acima traçado, verifica-se que as Constituições que antecederam a atual, não consideravam o índio como membro da comunidade nacional, mas sim uma mera parcela da população, alheia às demais. Assim, ao índio não era reconhecido o direito à manutenção de seu modo de vida, que era visto como um atraso cultural em relação aos demais brasileiros.

Por outro lado, restou evidente o reconhecimento de uma situação de fato que era a ocupação permanente de terras pelos indígenas.

\subsection{A Constituição de 1988}

Inicialmente, vale notar que além de dedicar um capítulo exclusivo aos direitos assegurados aos índios, a Constituição Federal de 1988 dedicou diversos tópicos às terras indígenas. Assim, pode-se citar, como exemplo, (i) a previsão no $\S 1^{\circ}$ do artigo $176^{28}$, o qual exige lei específica para o desenvolvimento de atividade garimpeira em terras indígenas, bem como (ii) o prazo de 05 (cinco) anos a contar da promulgação da Constituição Federal para demarcação de todas as terras indígenas existentes no país, estabelecido no artigo 67 do ADCT.

Contudo, foi no artigo 231 da Constituição que restou consagrado o reconhecimento aos índios dos direitos originários sobre as terras que tradicionalmente ocupam, conforme abaixo:

\footnotetext{
27 "Art. $4^{\circ}$ Incluem-se entre os bens da União: IV - as terras ocupadas pelos silvícolas".

28 "Art. 176. As jazidas, em lavra ou não, e demais recursos minerais e os potenciais de energia hidráulica constituem propriedade distinta da do solo, para efeito de exploração ou aproveitamento, e pertencem à União, garantida ao concessionário a propriedade do produto da lavra. $\S 1^{\circ}$ A pesquisa e a lavra de recursos minerais e o aproveitamento dos potenciais a que se refere o "caput" deste artigo somente poderão ser efetuados mediante autorização ou concessão da União, no interesse nacional, por brasileiros ou empresa constituída sob as leis brasileiras e que tenha sua sede e administração no País, na forma da lei, que estabelecerá as condições específicas quando essas atividades se desenvolverem em faixa de fronteira ou terras indígenas".
} 
Art. 231. São reconhecidos aos índios sua organização social, costumes, línguas, crenças e tradições, e os direitos originários sobre as terras que tradicionalmente ocupam, competindo à União demarcá-las, proteger e fazer respeitar todos os seus bens.

$\S 1^{\circ}$ São terras tradicionalmente ocupadas pelos índios as por eles habitadas em caráter permanente, as utilizadas para suas atividades produtivas, as imprescindíveis à preservação dos recursos ambientais necessários a seu bemestar e as necessárias a sua reprodução física e cultural, segundo seus usos, costumes e tradições.

$\S 2^{\circ}$ As terras tradicionalmente ocupadas pelos índios destinam-se a sua posse permanente, cabendo-lhes o usufruto exclusivo das riquezas do solo, dos rios e dos lagos nela existentes.

$\S 3^{\circ} \mathrm{O}$ aproveitamento dos recursos hídricos, incluídos os potenciais energéticos, a pesquisa e a lavra das riquezas minerais em terras indígenas só podem ser efetivados com autorização do Congresso Nacional, ouvidas as comunidades afetadas, ficando-lhes assegurada participação nos resultados da lavra, na forma da lei.

$\S 4^{\circ}$ - As terras de que trata este artigo são inalienáveis e indisponíveis, e os direitos sobre elas, imprescritíveis.

$\S 5^{\circ}$ - É vedada a remoção dos grupos indígenas de suas terras, salvo, "ad referendum" do Congresso Nacional, em caso de catástrofe ou epidemia que ponha em risco sua população, ou no interesse da soberania do País, após deliberação do Congresso Nacional, garantido, em qualquer hipótese, o retorno imediato logo que cesse o risco.

$\S 6^{\circ}$ - São nulos e extintos, não produzindo efeitos jurídicos, os atos que tenham por objeto a ocupação, o domínio e a posse das terras a que se refere este artigo, ou a exploração das riquezas naturais do solo, dos rios e dos lagos nelas existentes, ressalvado relevante interesse público da União, segundo o que dispuser lei complementar, não gerando a nulidade e a extinção direito a indenização ou a ações contra a União, salvo, na forma da lei, quanto às benfeitorias derivadas da ocupação de boa fé.

$\S 7^{\circ}$ - Não se aplica às terras indígenas o disposto no art. $174, \S 3^{\circ} \mathrm{e} \S 4^{\circ}$.

Assim, como se pode perceber, as terras indígenas são bens da União, com afetação exclusiva na posse dos índios e usufruto exclusivo das riquezas do solo, rios e lagos, não podendo ser alienada ou ter destinação diversa daquela determinada pela Constituição.

Com efeito, a maior garantia constitucional conferida aos índios é a nulidade de todos os atos praticados que tenham por objeto a ocupação, o domínio e a posse das terras indígenas, bem como a exploração das riquezas naturais nelas existentes.

Além disso, é importante destacar que, como se depreende do artigo 231 acima transcrito, o conceito constitucional de terras indígenas está 
relacionado à retirada da sobrevivência e à reprodução física e cultural da comunidade indígena em todos os seus aspectos.

De forma semelhante, já dispunha o artigo 23 do Estatuto do Índio (Lei ${ }^{\circ}$ 6.001/73):

Art $23^{\circ}$ Considera-se pose do índio ou silvícola a ocupação efetiva de terra, que, de acordo com os usos, costumes e tradições tribais, detém e onde habita ou exerce atividade indispensável à sua subsistência ou economicamente útil

Portanto, para que reste caracterizado o território indígena, vale dizer, o suporte material para as relações sociais, a cultura, as tradições e as crenças de cada comunidade indígena ${ }^{29}$, é preciso que ele, além de ser habitado em caráter permanente pelos índios, seja aproveitado segundo os seus peculiares usos, costumes e tradições, isto é, seja utilizado para garantir a sobrevivência física e cultural de cada povo.

Contudo, não basta o fato de que, em algum passado remoto, a terra tenha sido ocupada por índios para que ela seja reconhecida como Terra Indígena. O Supremo Tribunal Federal ao julgar o famoso caso da terra Indígena Raposa Serra do Sol, estabeleceu a data da promulgação da Constituição Federal de 1988 (5 de agosto de 1988) como marco temporal da ocupação da terra pelos indígenas e a tradicionalidade da sua ocupação, como se depreende do seguinte trecho do voto proferido pelo Ministro Carlos Ayres de Brito:

I - o marco temporal da ocupação. Aqui, é preciso ver que a nossa Lei Maior trabalhou com data certa: a data da promulgação dela própria $(5$ de outubro de 1988) como insubstituível referencial para o reconhecimento, aos índios, "dos direitos sobre as terras que tradicionalmente ocupam". Terras que tradicionalmente ocupam, atente-se, e não aquelas que venham a ocupar. Tampouco as terras já ocupadas em outras épocas, mas sem continuidade suficiente para alcançar o marco objetivo do dia 5 de outubro de 1988. Marco objetivo que reflete o decidido propósito constitucional de colocar uma pá de cal nas intermináveis discussões sobre qualquer outra referência temporal de ocupação de área indígena. 
Mesmo que essa referência estivesse grafada em Constituição anterior. É exprimir: a data de verificação do fato em si da ocupação fundiária é o dia 5 de outubro de 1988, e nenhum outro. Com o que se evita, a um só tempo: a) a fraude da subitânea proliferação de aldeias, inclusive mediante o recrutamento de índios de outras regiões do Brasil, quando não de outros países vizinhos, sob o único propósito de artificializar a expansão dos lindes da demarcação; b) a violência da expulsão de índios para descaracterizar a tradicionalidade da posse das suas terras, à data da vigente Constituição. Numa palavra, o entrar em vigor da nova Lei Fundamental Brasileira é a chapa radiográfica da questão indígena nesse delicado tema da ocupação das terras a demarcar pela União para a posse permanente e usufruto exclusivo dessa ou daquela etnia aborígine. Exclusivo uso e fruição (usufruto é isso, conforme Pontes de Miranda) quanto às "riquezas do solo, dos rios e dos lagos" existentes na área objeto de precisa demarcação ( $§ 2^{\circ}$ do art. art. 231), devido a que "os recursos minerais, inclusive os do subsolo", já fazem parte de uma outra categoria de "bens da União" (inciso IX do art. 20 da CF); II - o marco da tradicionalidade da ocupação. Não basta, porém, constatar uma ocupação fundiária coincidente com o dia e ano da promulgação do nosso Texto Magno. É preciso ainda que esse estar coletivamente situado em certo espaço fundiário se revista do caráter da perdurabilidade. Mas um tipo qualificadamente tradicional de perdurabilidade da ocupação indígena, no sentido entre anímico e psíquico de que viver em determinadas terras é tanto pertencer a elas quanto elas pertencerem a eles, os índios ("Anna Pata, Anna Yan": "Nossa Terra, Nossa Mãe"). ${ }^{30}$

Em outras palavras, para o reconhecimento aos índios dos direitos sobre as terras que tradicionalmente ocupam, é preciso que a referida ocupação fosse verificável quando da promulgação da Constituição Federal de 1988.

\subsection{Posse Permanente Indígena}

Conforme se viu acima, o conceito de posse permanente indígena não se confunde com o de posse civil, pois a ele se agrega a retirada da sobrevivência da comunidade indígena, em todos os seus amplos aspectos, como adiantado pelo voto do Ministro Victor Nunes Leal. Aliás, o voto já 
mencionado é um antepassado claro do conceito de terras tradicionalmente ocupadas contido no $\S 1^{\circ}$ do artigo 231 da vigente Constituição Federal ${ }^{31}$.

Dado o fato de que as terras indígenas não são de propriedade dos indígenas, mas apenas estão em sua posse, esta última pode ser perdida. Como já foi reconhecido pelo Pretório Excelso, rejeita-se o esbulho possessório e o desapossamento manu militari. Veja-se o voto proferido pelo eminente Ministro Ilmar Galvão, nos autos do Mandado de Segurança 21.575-5, do qual são transcritos os seguintes trechos:

Pedi vistas dos autos, porque, havendo bastado ao eminente relator, para concluir pela ilegitimidade do ato governamental impugnado, a circunstância, estreme de dúvida, de os "Kayowás" terem estado ausentes, por mais de 50 anos, das terras hoje registradas em nome dos impetrantes, considerei imperioso apurar se os referidos indígenas, entre 1938 e 1940, ao serem transferidos para a reserva "Takuapery", não haviam sido compelidos a deixar uma área de ocupação imemorial.[grifei] É que, se uma resposta positiva a essa indagação obviamente levar ao entendimento de que se tratava, no caso, de terras devolutas, suscetíveis de livre alienação pela unidade federada, por efeito da norma do art. 64 da Constituição de 1891, o mesmo não sucederia diante de hipótese contrária. Com efeito, demonstrado, ao revés, que se estava, em 1938, diante de terras tradicionalmente ocupadas pelos índios, já não se poderia aceitar, pacificamente, a solução apontada pelo eminente Relator, ainda que se comungue no entendimento, por ele esposado, de que a norma constitucional não teve o efeito de publicizar áreas já incorporadas ao domínio particular, nem de transferir para a União terras de domínio dos Estados. Pela singela razão de que, nesse caso, as terras em questão nunca teriam saído do domínio da União, havendo nele permanecido, vinculadas que se achavam à satisfação de direitos indígenas, direitos esses reconhecidos, desde famoso Alvará de $1^{\circ}$ de abril de 1680 , como originários, resultantes de uma relação jurídica fundada no instituto do indigenato, como fonte primária e congênita da posse territorial. ${ }^{32}$

Assim, resta evidente que há um dies a quo para o reconhecimento da posse permanente indígena, que é o da entrada em vigor da Constituição.

Caso os indígenas que reivindiquem uma determinada área não a ocupem permanentemente na data constitucional, deverá ser devidamente

31 "Art. 231. São reconhecidos aos índios sua organização social, costumes, línguas, crenças e tradições, e os direitos originários sobre as terras que tradicionalmente ocupam, competindo à União demarcá-las, proteger e fazer respeitar todos os seus bens. $\S 1^{\circ}$ - São terras tradicionalmente ocupadas pelos índios as por eles habitadas em caráter permanente, as utilizadas para suas atividades produtivas, as imprescindíveis à preservação dos recursos ambientais necessários a seu bem-estar e as necessárias a sua reprodução física e cultural, segundo seus usos, costumes e tradições".

$32 \quad$ STF, MS 21.575-5, Rel. Ministro Marco Aurélio, Brasília, 03 fev. 1994. 
comprovado que o desapossamento da área se deu de forma ilegítima, pois o desapossamento legítimo, como o da Carta Régia de 1808, gerou consequiências jurídicas para terceiros, constituindo-se em ato jurídico perfeito e acabado, merecedor de proteção constitucional.

O Supremo Tribunal Federal, por diversas vezes, já analisou questões referentes às chamadas Terras Indígenas e tem mantido posição firme no sentido de que o seu reconhecimento depende de uma condição prévia que é a efetiva posse pelos indígenas das terras reivindicadas. Tal condição não sofreu qualquer modificação com a Constituição de 1988, que apenas elevou ao nível constitucional os preceitos anteriormente existentes em nosso ordenamento jurídico.

\subsection{Requisitos Para o Reconhecimento de uma Comunidade Indígena - Convenção 169 OIT}

Como sabido, a Convenção 169 da Organização Internacional do Trabalho estabelece requisitos necessários para o reconhecimento de uma comunidade indígena. Efetivamente, determina o Artigo $1^{\circ}$ da Convenção:

Artigo $1^{\circ}$

1. A presente convenção aplica-se:

a) aos povos tribais em países independentes, cujas condições sociais, culturais e econômicas os distingam de outros setores da coletividade nacional, e que estejam regidos, total ou parcialmente, por seus próprios costumes ou tradições ou por legislação especial;

b) aos povos em países independentes, considerados indígenas pelo fato de descenderem de populações que habitavam o país ou uma região geográfica pertencente ao país na época da conquista ou da colonização ou do estabelecimento das atuais fronteiras estatais e que, seja qual for sua situação jurídica, conservam todas as suas próprias instituições sociais, econômicas, culturais e políticas, ou parte delas.

2. A consciência de sua identidade indígena ou tribal deverá ser considerada como critério fundamental para determinar os grupos aos que se aplicam as disposições da presente Convenção. 
No mesmo sentido, dispõe o Estatuto do Índio, em seu artigo $3^{\circ}$, inciso I, in verbis:

Art. $3^{\circ}$ Para os efeitos de lei, ficam estabelecidas as definições a seguir discriminadas:

I - Índio ou Silvícola - É todo indivíduo de origem e ascendência pré-colombiana que se identifica e é identificado como pertencente a um grupo étnico cujas características culturais o distinguem da sociedade nacional;

Assim, faz-se mister observar que a auto-identificação prevista no item 2 do artigo $1^{\circ}$ da Convenção da OIT é critério fundamental para o reconhecimento de determinada etnia indígena, e não critério determinante. Desta forma, referido critério é aplicável em conjunto com outros aspectos, devendo ser observados também se estes povos, além da consciência de sua natureza indígena ou tribal, conservam suas instituições sociais econômicas, culturais e políticas, ou parte delas que os distingam da coletividade nacional.

Nas palavras do professor Luiz Fernando Villares ${ }^{33}$ :

Tanto a Convenção 169 da OIT como o Estatuto do Índio definem que a origem histórica, a auto-identificação, a identificação pela comunidade e a conservação de determinadas características culturais institucionais são necessárias para definir o índio. Não parece que a Convenção 169 estabeleça auto-identificação como o único critério prescrito. Para a Convenção, "a consciência de sua identidade indígena ou tribal deverá ser considerada como critério fundamental para determinar os grupos". Ora, se é um critério fundamental, é o critério imprescindível, sem o qual uma pessoa não pode ser considerada como índio, então existem outros não-fundamentais, mas que são válidos. Por prever e permitir a existência de outros critérios, a Lei 6.001/73 não foi revogada.

Por outro lado, a Convenção, co essa norma, proíbe que alguém seja identificado como índio, independentemente de sua vontade e de seu auto-reconhecimento. É a proibição de rotular alguém numa qualificação em que o indivíduo mesmo não se reconheça, em algumas oportunidades utilizadas para segregar e discriminar a pessoa, impringindo-lhe um status renegado por ela.

\subsection{O Processo Demarcatório}

O caput do artigo 231 da Constituição Federal determinou ser de competência exclusiva da União, declarar e demarcar as terras indígenas.

33 VILLARES, Luiz Fernando. Direito e Povos Indígenas. Curitiba: Ed. Juruá, 2009. p. 31/32. 
Em complemento ao dispositivo constitucional, o Estatuto do Índio, em seu artigo 19, estabeleceu o seguinte:

"Art. 19 As terras indígenas, por iniciativa e sob orientação do órgão federal de assistência ao índio, serão administrativamente demarcadas, de acordo com o processo estabelecido em decreto do Poder Executivo."

Assim, a demarcação foi regulamentada pelo Decreto $\mathrm{n}^{\circ} 1.775$, de 8 de janeiro de 1996, o qual estabelece as regras obre o procedimento administrativo de demarcação de terras indígenas.

Como sabido, a demarcação consiste em definir os limites de um território, colocando-se marcas físicas, marcos artificiais e estabelecendo os marcos naturais, a fim de determinar a área de posse indígena. Contudo, para demarcar é necessário identificá-las.

O processo administrativo de demarcação de uma terra indígena é iniciado a partir do conhecimento pela Fundação Nacional do Índio FUNAI de uma terra indígena a ser demarcada ou um pleito, dos próprios índios, de suas organizações ou de entidades governamentais e nãogovernamentais. Tal procedimento pode ser deflagrado por atos de outros órgãos do Estado, vinculados à União, estados ou municípios, como, por exemplo, a construção de empreendimentos ou constituição de áreas ambientalmente protegidas, os quais exercem uma pressão territorial à ocupação indígena. Nestes casos, as demarcações são de extrema importância para evitar situações irreversíveis ou de sérios impactos nas terras indígenas.

Após tomar conhecimento da terra indígena a ser demarcada, a FUNAI analisa os pleitos a fim de verificar sua urgência e pertinência, isto é, a fundamentação técnica preliminar e viabilidade política da demarcação.

O procedimento se inicia com a designação, por portaria do Presidente da FUNAI, do Grupo de Trabalho composto por servidores do próprio quadro funcional ou especialistas de fora da Administração Pública, o qual, coordenado por antropólogo qualificado, ficará responsável pela 
realização de estudos antropológicos de identificação da terra indígena. Referido grupo de trabalho poderá ser constituído, também, de outros profissionais a fim de complementar o estudo antropológico com informações históricas, sociológicas, jurídicas, cartográficas, ambientais e fundiárias necessárias para a identificação da terra indígena.

É importante destacar que a instauração de Grupo de Trabalho pela FUNAI é marco inicial e fundamental do reconhecimento de uma terra indígena.

Os estudos realizados pelo Grupo de Trabalho contarão com a participação do grupo indígena envolvido, o qual deverá participar do procedimento em todas as suas fases, conforme determina o $\$ 3^{\circ}$, do art. $2^{\circ}$ do Decreto $1.775 / 96^{34}$.

No prazo de trinta dias, a contar da publicação do ato que constituir o Grupo de Trabalho, deverão ser apresentadas as informações que instruirão os estudos do grupo.

Realizados os estudos de identificação, o grupo apresenta relatório circunstanciado ao órgão federal de assistência ao índio, analisando a existência ou não de ocupação tradicional da terra indígena. Caso o relatório conclua pela existência da ocupação tradicional, deverá apresentar, ainda que preliminarmente, proposta de área a ser delimitada ${ }^{35}$. Em seguida, o relatório é apresentado para a FUNAI, podendo seu titular aprová-lo, determinar que seja complementado ou, ainda, rejeitá-lo, decidindo inclusive sobre o mérito da proposta.

Aprovado o relatório pelo titular da FUNAI, um resumo do relatório, acompanhado de memorial descritivo e mapa da área, deverá ser publicado

\footnotetext{
34 "Art. $2^{\circ}$ A demarcação das terras tradicionalmente ocupadas pelos índios será fundamentada em trabalhos desenvolvidos por antropólogo de qualificação reconhecida, que elaborará, em prazo fixado na portaria de nomeação baixada pelo titular do órgão federal de assistência ao índio, estudo antropológico de identificação. $\S 3^{\circ} \mathrm{O}$ grupo indígena envolvido, representado segundo suas formas próprias, participará do procedimento em todas as suas fases".

O relatório circunstanciado de identificação e delimitação de terras indígenas a que se refere o $\S 6^{\circ}$ do artigo $2^{\circ}$ do Decreto $1.775 / 96$ tem sua forma e conteúdo regulamentado pela Portaria $\mathrm{n}^{\circ} 14$, de 09 de janeiro de 1996, do Ministério da Justiça.
} 
no prazo de quinze dias no Diário Oficial da União e nos diários oficiais dos estados onde se localiza a área sob demarcação. Além disso, a publicação deverá ser afixada na sede da Prefeitura Municipal da situação do imóvel.

A partir da publicação, os Estados e Municípios em que se localiza a terra sob demarcação e os demais interessados têm o prazo de 90 (noventa) dias para apresentar contestações perante a FUNAI. Vale ressaltar que, esse é o momento de maior amplitude no oferecimento das razões favoráveis ou contrárias às conclusões do grupo técnico nomeado pela FUNAI.

Apresentadas as referidas contestações, o órgão indigenista tem o prazo de sessenta dias para analisá-las, oferecendo seu parecer. Na hipótese de serem admitidas as razões do recurso, o órgão poderá rever sua decisão, sanando eventuais vícios do procedimento ou mudando seu juízo de aprovação do território. Caso o órgão indigenista entenda pela denegação das razões apresentadas, deverá encaminhar o procedimento para o Ministro de Estado da Justiça, o qual poderá, em trinta dias, (i) desaprovar a identificação e retornar os autos ao órgão indigenista, por meio de decisão fundamentada no não atendimento do disposto no $\S 1^{\circ}$ do $\operatorname{artigo} 231$ da Constituição $^{36}$ e demais disposições pertinentes; (ii) prescrever diligências que julgue necessárias, que deverão ser cumpridas pela FUNAI em noventa dias; ou (iii) declarar, mediante portaria, os limites da terra indígena e determinar sua demarcação.

Caso a terra seja declarada como tradicionalmente ocupada por índios, é realizado o trabalho de demarcação propriamente dito, por meio do qual são colocados os marcos físicos que delimitarão a área da terra indígena. É nesta fase que é realizado o levantamento das benfeitorias, bem

\footnotetext{
36 "Art. 231. São reconhecidos aos índios sua organização social, costumes, línguas, crenças e tradições, e os direitos originários sobre as terras que tradicionalmente ocupam, competindo à União demarcá-las, proteger e fazer respeitar todos os seus bens. $\S 1^{\circ}$ - São terras tradicionalmente ocupadas pelos índios as por eles habitadas em caráter permanente, as utilizadas para suas atividades produtivas, as imprescindíveis à preservação dos recursos ambientais necessários a seu bem-estar e as necessárias a sua reprodução física e cultural, segundo seus usos, costumes e tradições".
} 
como o pagamento de indenização às benfeitorias derivadas da ocupação de boa fé (Artigo 231, $\S 6^{\circ}$ da Constituição Federal).

Realizada a demarcação física, ela é homologada por meio de decreto presidencial, que consiste em ato administrativo que reconhece a legalidade de todo o procedimento demarcatório, possuindo caráter meramente declaratório eis que não cria, extingue ou modifica relações jurídicas, apenas reconhecendo a nulidade e extinção dos atos que tenham por objeto a ocupação, o domínio e a posse das terras.

Assim, é importante ressaltar que o direito indígena de habitar suas terras e delas usufruir é anterior ao reconhecimento formal pelo Estado, no entanto, o procedimento administrativo é necessário para produzir efeitos jurídicos e fáticos.

Como dito acima, por vezes, a implantação de empreendimentos pode deflagrar a abertura de procedimento administrativo para demarcação de terras indígenas. Assim, passemos a analisar como se dá a avaliação ambiental de referidos empreendimentos. 


\section{LICENCIAMENTO AMBIENTAL}

\subsection{Panorama Geral}

A Constituição Federal de 1988, além de dedicar um capítulo exclusivo aos direitos indígenas, também o fez com relação ao meio ambiente, considerando-o um bem de uso como do povo e assegurando sua defesa e preservação não só para as presentes como para as futuras gerações.

Dentre os mecanismos que estão à disposição do Poder Público para garantir a preservação do meio ambiente, o licenciamento ambiental é considerado o mais importante e eficaz, eis que permite um controle prévio e efetivo pelo Poder Público das atividades potencialmente danosas ao meio ambiente, por meio da imposição de exigências para o regular exercício destas atividades.

Sendo assim, referido instrumento é considerado como o principal instrumento do Poder Público para o exercício do poder de polícia ambiental.

\subsection{O Licenciamento Ambiental}

\subsubsection{Um Instrumento de Controle Prévio}

A Constituição Federal, em seu artigo $225^{37}$, estabelece que o meio ambiente ecologicamente equilibrado é bem de uso comum do povo, essencial à sadia qualidade de vida. Assim, por ser de todos e de ninguém

\footnotetext{
37 "Art. 225. Todos têm direito ao meio ambiente ecologicamente equilibrado, bem de uso comum do povo e essencial à sadia qualidade de vida, impondo-se ao Poder Público e à coletividade o dever de defendê-lo e preservá-lo para as presentes e futuras gerações".
} 
em particular, somente se legitima mediante a atuação do Poder Público, que tem o dever de defendê-lo e preservá-lo para as presentes e futuras gerações. Para assegurar a efetividade do direito ao meio ambiente ecologicamente equilibrado, o Poder Público tem a incumbência de tomar as providências enumeradas no $\S 1^{\circ}$ do referido artigo $225^{38}$, entre elas, a exigência de Estudo Prévio de Impacto Ambiental para instalação de atividade potencialmente causadora de significativo impacto ao meio ambiente.

Por sua vez, a Lei 6.938, de 31 de agosto de 1981, que instituiu a Política Nacional do Meio Ambiente, previu instrumentos de controle prévio, entre os quais se destaca o licenciamento para a instalação de obras ou atividades potencialmente poluidoras, conforme disposto em seu artigo $9^{\circ}$, inciso $\mathrm{IV}^{39}$.

Ao regulamentar a matéria, a Resolução CONAMA 237, de 19 de dezembro de 1997, definiu o licenciamento ambiental como o "procedimento administrativo pelo qual o órgão ambiental competente licencia a localização, instalação, ampliação e a operação de empreendimentos e atividades utilizadoras de recursos ambientais, consideradas efetiva ou potencialmente poluidoras ou daquelas que, sob qualquer forma, possam causar degradação ambiental, considerando as

\footnotetext{
38 "Art. 225. Todos têm direito ao meio ambiente ecologicamente equilibrado, bem de uso comum do povo e essencial à sadia qualidade de vida, impondo-se ao Poder Público e à coletividade o dever de defendê-lo e preservá-lo para as presentes e futuras gerações. $\S 1^{\circ}$ - Para assegurar a efetividade desse direito, incumbe ao Poder Público: I - preservar e restaurar os processos ecológicos essenciais e prover o manejo ecológico das espécies e ecossistemas; (Regulamento); II - preservar a diversidade e a integridade do patrimônio genético do País e fiscalizar as entidades dedicadas à pesquisa e manipulação de material genético; (Regulamento); III - definir, em todas as unidades da Federação, espaços territoriais e seus componentes a serem especialmente protegidos, sendo a alteração e a supressão permitidas somente através de lei, vedada qualquer utilização que comprometa a integridade dos atributos que justifiquem sua proteção; (Regulamento); IV - exigir, na forma da lei, para instalação de obra ou atividade potencialmente causadora de significativa degradação do meio ambiente, estudo prévio de impacto ambiental, a que se dará publicidade; (Regulamento); V - controlar a produção, a comercialização e o emprego de técnicas, métodos e substâncias que comportem risco para a vida, a qualidade de vida e o meio ambiente; (Regulamento); VI - promover a educação ambiental em todos os níveis de ensino e a conscientização pública para a preservação do meio ambiente; VII - proteger a fauna e a flora, vedadas, na forma da lei, as práticas que coloquem em risco sua função ecológica, provoquem a extinção de espécies ou submetam os animais a crueldade. (Regulamento)".

"Art $9^{\circ}$ - São instrumentos da Política Nacional do Meio Ambiente: IV - o licenciamento e a revisão de atividades efetiva ou potencialmente poluidoras".
} 
disposições legais e regulamentares e as normas aplicáveis ao caso" (artigo $1^{\circ}$, inciso I $)^{40}$.

Assim, o licenciamento ambiental consiste em um procedimento administrativo que permite ao Poder Público avaliar as condições para a instalação de atividades efetiva ou potencialmente poluidoras, de forma a assegurar que tais atividades causem o menor impacto ambiental possível. Referido procedimento culmina na expedição de uma licença ambiental.

A licença ambiental, por sua vez, consiste no ato administrativo pelo qual o órgão ambiental estabelece as condições a serem observadas pelo empreendedor para instalar a atividade considerada efetiva ou potencialmente poluidora.

No Brasil, o procedimento de licenciamento ambiental compreende a concessão de uma licença prévia, uma licença de instalação e uma licença de operação, conforme disposto no art. $8^{\circ}$ da Resolução CONAMA 237/1997, abaixo transcrito:

Art. $8^{\circ}$ - O Poder Público, no exercício de sua competência de controle, expedirá as seguintes licenças:

I - Licença Prévia (LP) - concedida na fase preliminar do planejamento do empreendimento ou atividade aprovando sua localização e concepção, atestando a viabilidade ambiental e estabelecendo os requisitos básicos e condicionantes a serem atendidos nas próximas fases de sua implementação;

II - Licença de Instalação (LI) - autoriza a instalação do empreendimento ou atividade de acordo com as especificações constantes dos planos, programas e projetos aprovados, incluindo as medidas de controle ambiental e demais condicionantes, da qual constituem motivo determinante;

III - Licença de Operação (LO) - autoriza a operação da atividade ou empreendimento, após a verificação do efetivo cumprimento do que consta das licenças anteriores, com as medidas de controle ambiental e condicionantes determinados para a operação.

Parágrafo único - As licenças ambientais poderão ser expedidas isolada ou sucessivamente, de acordo com a natureza, características e fase do empreendimento ou atividade.

40 "Art. $1^{\text {o }}$ - Para efeito desta Resolução são adotadas as seguintes definições I Licenciamento Ambiental: procedimento administrativo pelo qual o órgão ambiental competente licencia a localização, instalação, ampliação e a operação de empreendimentos e atividades utilizadoras de recursos ambientais, consideradas efetiva ou potencialmente poluidoras ou daquelas que, sob qualquer forma, possam causar degradação ambiental, considerando as disposições legais e regulamentares e as normas técnicas aplicáveis ao caso". 


\subsubsection{Ato Exclusivo do Poder Executivo}

O artigo 23, VI, da Constituição Federal ao dispor sobre a atuação da Administração Pública, definiu ser de competência comum da União, Estados, Municípios e Distrito Federal "proteger o meio ambiente e combater a poluição em qualquer de suas formas".

Ao determinar a competência comum dos entes federativos do Poder Executivo no que diz respeito à proteção do meio ambiente, o artigo 23 acima mencionado, tratou da competência administrativa, determinando que União, Estados, Municípios e Distrito Federal são solidariamente responsáveis pela proteção do meio ambiente, na qual se insere o licenciamento ambiental.

Nesse sentido, Paulo de Bessa Antunes nos ensina que:

Quanto à competência tratada pelo artigo 23, a competência comum, ela não é legislativa. Trata-se como indicado acima, de cooperação administrativa, como lembrado por José Cretella Jr.: 'Competência comum é cooperação administrativa, tendo em vista o equilíbrio do desenvolvimento do bem-estar, em âmbito nacional, entre a União, os Estados, o Distrito Federal e os Municípios, o exercício de funções concomitantes e contínuas, que incidem sobre as matérias constantes dos incisos I a XII do art. 23 da Carta Política de 1988, o auxílio recíproco disciplinado por normas veiculadas por lei complementar federal. Nesta expressão "comum" é sinônimo de "concorrente", como o era na Constituição de 1934, art. 10, III (concorrentemente). Trata-se, porém, da "concorrência administrativa'. A competência comum, portanto, é uma imposição constitucional para que os membros da federação atuem em cooperação administrativa recíproca, visando a resguardar os bens ambientais ${ }^{41}$.

Em complementação ao referido entendimento, Paulo José Leite Farias,

ao tratar da competência federativa e a proteção do meio ambiente, anota:

Assim como ocorre com o conceito de jurisdição, que é, em tese e por excelência, uno e indivisível, o conceito de administração, nota distintiva da autonomia que caracteriza os entes integrantes do pacto federativo, também não admite divisões. Aceita-se, o que é diferente, a repartição do exercício de competências administrativas, para que, na prática, seja viável a sua prestação. Nesse contexto deve ser entendida a previsão do artigo 23 , incisos VI e VII, bem como seu parágrafo único, na Constituição Federal. ${ }^{42}$

41 ANTUNES, Paulo de Bessa. Federalismo e Competências Ambientais no Brasil. 11 ${ }^{\text {a }}$ Ed. Rio de Janeiro: Lúmen Júris, 2007, p. 108

42 FARIAS, Paulo José Leite. Competência Federativa e Proteção Ambiental. Porto Alegre: Sergio Antonio Fabris Editor, 1999, p.312. 
Assim, apenas União, Estados, Municípios e o Distrito Federal possuem legitimidade para proceder ao licenciamento ambiental de empreendimentos ou atividades efetiva ou potencialmente poluidores.

Respaldando referido entendimento, ressalta-se que o licenciamento ambiental é o principal instrumento à disposição da Administração Pública para o exercício do poder de polícia ambiental, o qual é restrito ao âmbito da competência do Poder Executivo.

Ao definir o poder de polícia, Paulo de Bessa Antunes aponta que "o conceito de poder de polícia é vinculado a prerrogativas e deveres da Administração Pública como estrutura encarregada de assegurar um mínimo de coesão social, dentro dos limites do Estado de Direito". ${ }^{43}$

Diante do exposto, verifica-se que sob qualquer independente da ótica em que se analise a matéria, o licenciamento ambiental é ato exclusivo do Poder Executivo.

\subsubsection{Etapas do Licenciamento Ambiental}

O procedimento administrativo de licenciamento ambiental se desenvolve em diversas etapas, as quais foram delineadas no artigo $10 \mathrm{da}$ Resolução CONAMA 237/1997, que dispõe o seguinte:

Art. 10 - O procedimento de licenciamento ambiental obedecerá às seguintes etapas: I - Definição pelo órgão ambiental competente, com a participação do empreendedor, dos documentos, projetos e estudos ambientais, necessários ao início do processo de licenciamento correspondente à licença a ser requerida; II - Requerimento da licença ambiental pelo empreendedor, acompanhado dos documentos, projetos e estudos ambientais pertinentes, dando-se a devida publicidade;

III - Análise pelo órgão ambiental competente, integrante do SISNAMA, dos documentos, projetos e estudos ambientais apresentados e a realização de vistorias técnicas, quando necessárias;

IV - Solicitação de esclarecimentos e complementações pelo órgão ambiental competente, integrante do SISNAMA, uma única vez, em decorrência da análise dos documentos, projetos e estudos ambientais apresentados, quando couber,

43 ANTUNES, Paulo de Bessa. Direito Ambiental. 9a Ed. Rio de Janeiro: Lúmen Júris, 2007, p. 121. 
podendo haver a reiteração da mesma solicitação caso os esclarecimentos e complementações não tenham sido satisfatórios;

V - Audiência pública, quando couber, de acordo com a regulamentação pertinente;

VI - Solicitação de esclarecimentos e complementações pelo órgão ambiental competente, decorrentes de audiências públicas, quando couber, podendo haver reiteração da solicitação quando os esclarecimentos e complementações não tenham sido satisfatórios;

VII - Emissão de parecer técnico conclusivo e, quando couber, parecer jurídico;

VIII - Deferimento ou indeferimento do pedido de licença, dando-se a devida publicidade.

De maneira geral, o licenciamento ambiental deve ser baseado em estudos técnicos que tem por objetivo avaliar o impacto que determinada atividade poderá ocasionar ao meio ambiente. Cada etapa acima prevista será fundada nos referidos estudos ambientais, de forma a respaldar as decisões a serem tomadas pelo Poder Público.

Neste sentido, é importante observar o teor do inciso III do artigo $1^{\circ}$ da Resolução CONAMA 237/1997, que define os estudos ambientais, dispondo também sobre os formatos que eles poderão assumir:

Art. $1^{\circ}$ - Para efeito desta Resolução são adotadas as seguintes definições:

III - Estudos Ambientais: são todos e quaisquer estudos relativos aos aspectos ambientais relacionados à localização, instalação, operação e ampliação de uma atividade ou empreendimento, apresentado como subsídio para a análise da licença requerida, tais como: relatório ambiental, plano e projeto de controle ambiental, relatório ambiental preliminar, diagnóstico ambiental, plano de manejo, plano de recuperação de área degradada e análise preliminar de risco.

Dentre os referidos estudos, destaca-se o EIA/RIMA - Estudo de Impacto Ambiental e seu respectivo Relatório de Impacto Ambiental, o qual encontra previsão constitucional, devendo instruir o pedido de licença ambiental nos casos de empreendimentos efetiva ou potencialmente causadores de significativo impacto ambiental, conforme será abordado no próximo item.

Por outro lado, nos casos em que o empreendimento não seja efetiva ou potencialmente causador de significativo impacto ambiental, o órgão ambiental competente definirá os estudos ambientais pertinentes ao 
licenciamento daquela atividade. Pode-se citar como exemplo o Relatório de Controle Ambiental - RCA, criado inicialmente para as hipóteses de dispensa do EIA/RIMA para obtenção de Licença Prévia - LP, em casos de extração de minérios, cujo empreendimento seja de menor porte e o Plano de Controle Ambiental - PCA, exigido inicialmente para concessão da Licença de Instalação - LI de atividade de extração mineral, destinado a propor diretrizes para o monitoramento ambiental do empreendimento e o projeto executivo de implantação das medidas mitigadoras ou corretivas.

Aprovado o respectivo estudo ambiental, são emitidas ou não as licenças ambientais, explicitadas no item anterior, devendo ser observada em todas as etapas a publicidade dos atos praticados.

Importante destacar, ainda, que o parágrafo primeiro do artigo 10 da Resolução CONAMA 237/11974, acima transcrito, determina que os requerimentos de licenças ambientais devem ser instruídos com certidão emitida pelas Prefeituras Municipais, declarando que o empreendimento encontra-se em conformidade com o zoneamento municipal.

\subsubsection{Competências para Realização do Licenciamento Ambiental}

Como dito acima, a Constituição Federal, em seu artigo $23^{45}$, determina que a União, os Estados, o Distrito Federal e os Municípios têm competência comum para proteger o meio ambiente e combater a poluição em qualquer de suas formas; preservar as florestas, a flora e a fauna.

\footnotetext{
44 "Art. 10 - O procedimento de licenciamento ambiental obedecerá às seguintes etapas: (...) $\S 1^{\circ}$ - No procedimento de licenciamento ambiental deverá constar, obrigatoriamente, a certidão da Prefeitura Municipal, declarando que o local e o tipo de empreendimento ou atividade estão em conformidade com a legislação aplicável ao uso e ocupação do solo e, quando for o caso, a autorização para supressão de vegetação e a outorga para o uso da água, emitidas pelos órgãos competentes".

45 "Art. 23. É competência comum da União, dos Estados, do Distrito Federal e dos Municípios: VI - proteger o meio ambiente e combater a poluição em qualquer de suas formas".
} 
$\mathrm{O}$ artigo 24 da Constituição $\mathrm{Federal}^{46}$, por sua vez, determina competir à União, aos Estados e ao Distrito Federal legislar concorrentemente sobre florestas, caça. Pesca, fauna, conservação, defesa do meio e dos recursos naturais, proteção ao meio ambiente e controle da poluição.

Assim, a Constituição Federal, ao determinar que os diferentes entes federados devam compartilhar responsabilidades no que diz respeito à proteção do meio ambiente, seja quanto à competência legislativa, seja quanto à competência de implementação, consagrou o chamado federalismo cooperativo.

Contudo, o modelo de federalismo adotado pelo legislador constituinte tem se caracterizado por ser extremamente centralizador e competitivo, ao invés de cooperativo.

Como se sabe, o licenciamento ambiental é uma atividade administrativa que permite o controle ambiental preventivo e efetivo pelo poder público, possuindo, portanto, caráter essencialmente de tutela e, nesta condição, enquadra-se no âmbito de competência de implementação, e, portanto, na chamada competência comum.

Em nível constitucional, o licenciamento ambiental é arrolado na competência comum disciplinada pelo artigo 23, inciso VI da CF. A Política Nacional do Meio Ambiente, instituída pela Lei 6.938, de 31 de agosto de 1981, estabeleceu o relacionamento político-institucional entre os entes federados, buscando articular um regime de mútua colaboração com a construção de modelo institucional integrador, e optando por ações descentralizadas.

A Lei 6.938/81, em seu artigo 10, estabeleceu repartição de competências ambientais para o licenciamento, conforme abaixo:

46 "Art. 24. Compete à União, aos Estados e ao Distrito Federal legislar concorrentemente sobre: VI - florestas, caça, pesca, fauna, conservação da natureza, defesa do solo e dos recursos naturais, proteção do meio ambiente e controle da poluição". 
Art. 10 - A construção, instalação, ampliação e funcionamento de estabelecimentos e atividades utilizadoras de recursos ambientais, considerados efetiva e potencialmente poluidores, bem como os capazes, sob qualquer forma, de causar degradação ambiental, dependerão de prévio licenciamento de órgão estadual competente, integrante do Sistema Nacional do Meio Ambiente SISNAMA, e do Instituto Brasileiro do Meio Ambiente e Recursos Naturais Renováveis - IBAMA, em caráter supletivo, sem prejuízo de outras licenças exigíveis. (Redação dada pela Lei ${ }^{\circ} 7.804$, de 1989)

$\S 1^{\circ}$ - Os pedidos de licenciamento, sua renovação e a respectiva concessão serão publicados no jornal oficial do Estado, bem como em um periódico regional ou local de grande circulação.

$\S 2^{\circ}$ Nos casos e prazos previstos em resolução do CONAMA, o licenciamento de que trata este artigo dependerá de homologação do IBAMA. (Redação dada pela Lei $\mathrm{n}^{\circ} 7.804$, de 1989)

$\S 3^{\circ} \mathrm{O}$ órgão estadual do meio ambiente e o IBAMA, esta em caráter supletivo, poderão, se necessário e sem prejuízo das penalidades pecuniárias cabíveis, determinar a redução das atividades geradoras de poluição, para manter as emissões gasosas, os efluentes líquidos e os resíduos sólidos dentro das condições e limites estipulados no licenciamento concedido. (Redação dada pela Lei ${ }^{\circ}$ 7.804, de 1989)

$\S 4^{\circ}$ Compete ao Instituto Brasileiro do Meio Ambiente e Recursos Naturais Renováveis - IBAMA o licenciamento previsto no caput deste artigo, no caso de atividades e obras com significativo impacto ambiental, de âmbito nacional ou regional. (Redação dada pela Lei $n^{\circ} 7.804$, de 1989)

Pela leitura do referido artigo, nota-se que a lei adotou como norma geral a competência estadual para o licenciamento ambiental, sendo atribuição do IBAMA o licenciamento em caráter supletivo ou excepcional, de caráter nacional ou regional, na forma do $\S 4^{\circ}$ do referido artigo. Importante destacar que não há qualquer menção na Lei da PNMA quanto ao licenciamento municipal, razão pela qual este é considerado uma exceção ao critério geral.

No mesmo sentido, estão as disposições do Decreto n ${ }^{\circ} 99.274$ de 06 de junho de 1990, que regulamentou a Lei 6938/81, o qual prevê, em seu artigo $17^{47}$, que os empreendimentos capazes de causar degradação ambiental dependerão de prévio licenciamento do órgão estadual.

\footnotetext{
47 "Art. 17. A construção, instalação, ampliação e funcionamento de estabelecimento de atividades utilizadoras de recursos ambientais, consideradas efetiva ou potencialmente poluidoras, bem assim os empreendimentos capazes, sob qualquer forma, de causar degradação ambiental, dependerão de prévio licenciamento do órgão estadual competente integrante do Sisnama, sem prejuízo de outras licenças legalmente exigíveis".
} 
Com referência ao papel a ser desempenhado pelos órgãos ambientais no licenciamento ambiental, Paulo de Bessa Antunes nos ensina que:

O Instituto Brasileiro do Meio Ambiente e dos Recursos Naturais Renováveis IBAMA exerce funções de caráter supletivo na atividade de licenciamento ambiental e na conseqüente fiscalização do efetivo cumprimento os termos nos quais foi concedida a licença; isto porque o licenciamento é fundamentalmente desempenhado pelos órgãos estaduais integrantes do SISNAMA - Sistema Nacional do Meio Ambiente. Por atividade supletiva não se deve entender uma atividade exercida em substituição daquela que deve ser desempenhada pelo órgão estadual de controle ambiental, salvo nas hipóteses em que o órgão regional não exista. A atividade supletiva limita-se a atender aspectos secundários do processo de licenciamento. Não pode, contudo, o órgão federal, "discordar" da licença concedida pelo órgão estadual e, na vigência desta, embargas obras etc. Isto somente pode ocorrer, em tese, se o órgão federal demonstrar que a licença estadual está eivada de vício. A observância deste parâmetro de atribuição administrativa é fundamental para que o SISNAMA possa, de fato, existir. Se se admitisse que os órgãos públicos de diferentes esferas federativas pudessem, a seu talante, embargar, paralisar e contestar atividades que se encontram autorizadas regularmente pelos demais integrantes do SISNAMA, no uso normal e legal de suas atribuições, o sistema se tornaria completamente inviável. Aliás, a própria criação do Sisnama tem por finalidade última a organização de atribuições diferenciadas e a descentralização administrativa de forma cooperativa e harmônica. Desejo ressaltar que, evidentemente, no uso da competência administrativa residual de cada um dos integrantes do SISNAMA, é plenamente possível que sejam necessárias licenças diversas e que a concessão de uma delas, por si só, não seja suficiente para autorizar determinado empreendimento. Nesta hipótese, é possível a oposição de embargos administrativos a empreendimentos que não possuam todas as licenças necessárias. ${ }^{48}$

No mesmo sentido é a jurisprudência:

MANDADO DE SEGURANÇA. POSTO REVENDEDOR DE DERIVADOS DE PETRÓLEO. AUTUAÇÃO E INTERDIÇÃO PELO IBAMA POR AUSÊNCIA DE LICENCIAMENTO AMBIENTAL. COMPETÊNCIA SUPLETIVA DO IBAMA. LEIS 6.938/81 E 9.605/98. IRREGULARIDADES. PROVA PRÉ-CONSTITUÍDA. AUSÊNCIA DE DIREITO LÍQUIDO E CERTO.

1. A Lei $\mathrm{n}^{\circ} 6.938 / 81$ confere competência supletiva ao IBAMA para fiscalizar as atividades consideradas potencial e efetivamente poluidoras e a Lei $\mathrm{n}^{\circ} 9.605 / 98$ estabelece sua competência para autuar e instaurar processo administrativo contra condutas lesivas ao meio ambiente.

2. O fato de o pedido de licenciamento ambiental estar em trâmite junto à Secretaria do Meio Ambiente do Distrito Federal - SEMARH não retira a competência do IBAMA para exercer o seu poder de polícia sobre atividades potencialmente poluidoras. 49 :

48 ANTUNES, Paulo de Bessa. Direito Ambiental, Rio de Janeiro, Lúmen Júris, 9a edição, p. $133-134$ TRF - PRIMEIRA REGIÃO, AMS 200334000003628, Rel. Desembargadora Federal Selene Maria de Almeida, Distrito Federal, 13 dez. 2004. 
3. A atuação supletiva do IBAMA, apesar de a lei não indicar os seus parâmetros, deverá ocorrer, principalmente, em duas situações: se o órgão estadual ambiental for inepto ou se o órgão permanecer inerte ou omisso.

4. Diante da farta prova produzida pelo IBAMA, não refutada pela recorrente, que não logrou trazer prova pré-constituída capaz de neutralizar a força probante dos laudos produzidos pelo órgão público, dúvida não há quanto à conduta lesiva ao meio ambiente.

5. Apelação improvida.

Pela regra geral estabelecida na PNMA, não restam dúvidas de que a competência para o licenciamento deve ser atribuída ao órgão ambiental estadual. Contudo, as circunstâncias especiais do caso concreto podem indicar a existência de interesse municipal para a realização do licenciamento, o que ensejaria aplicação da exceção à regra geral.

A atribuição do licenciamento ambiental aos Municípios é tema que tem sido amplamente debatido em matéria de tutela de recursos naturais. Cada vez mais, os Municípios vêm ampliando sua atuação no que tange ao controle de atividades potencialmente danosas ao meio ambiente, editando legislação própria e estruturando órgãos administrativos para tal função.

A Resolução CONAMA 237/97 estabeleceu que compete ao órgão ambiental municipal o licenciamento de atividades de impacto local e daquelas que lhe forem delegadas pelo Estado, por instrumento legal ou convênio. ${ }^{50}$ A Resolução determinou ainda que os entes federados, para exercerem suas competências licenciatórias, devem implementar os Conselhos de Meio Ambiente, além de possuir em seus quadros, ou à sua disposição, profissionais legalmente habilitados ${ }^{51}$.

Cumpre ressaltar que a referida resolução possui constitucionalidade controversa por conter dispositivos que deveriam estar previstos em lei complementar, na forma do parágrafo único do artigo 23 da Constituição

\footnotetext{
50 "Art. $6^{\circ}$ - Compete ao órgão ambiental municipal, ouvidos os órgãos competentes da União, dos Estados e do Distrito Federal, quando couber, o licenciamento ambiental de empreendimentos e atividades de impacto ambiental local e daquelas que lhe forem delegadas pelo Estado por instrumento legal ou convênio".

51 "Art. 20 - Os entes federados, para exercerem suas competências licenciatórias, deverão ter implementados os Conselhos de Meio Ambiente, com caráter deliberativo e participação social e, ainda, possuir em seus quadros ou a sua disposição profissionais legalmente habilitados".
} 
Federal $^{52}$, e não em mero regulamento. Assim, destaca-se que o CONAMA não possui atribuição para inovar no mundo jurídico e alterar os critérios estabelecidos pela Lei $\mathrm{n}^{\circ} 6.938 / 81$ e pelo Decreto 99.274/90, que instituíram como regra a competência estadual para o licenciamento ambiental.

Não obstante o disposto acima, a Resolução CONAMA 237/1997 dispôs sobre a definição do que seriam empreendimentos e atividades com significativo impacto ambiental de âmbito nacional ou regional, listando as seguintes hipóteses:

Art. $1^{\circ}$ - Para efeito desta Resolução são adotadas as seguintes definições:

IV - Impacto Ambiental Regional: é todo e qualquer impacto ambiental que afete diretamente (área de influência direta do projeto), no todo ou em parte, o território de dois ou mais Estados.

Art. $4^{\circ}$ - Compete ao Instituto Brasileiro do Meio Ambiente e dos Recursos Naturais Renováveis - IBAMA, órgão executor do SISNAMA, o licenciamento ambiental, a que se refere o artigo 10 da Lei $n^{\circ} 6.938$, de 31 de agosto de 1981, de empreendimentos e atividades com significativo impacto ambiental de âmbito nacional ou regional, a saber:

I - localizadas ou desenvolvidas conjuntamente no Brasil e em país limítrofe; no mar territorial; na plataforma continental; na zona econômica exclusiva; em terras indígenas ou em unidades de conservação do domínio da União.

II - localizadas ou desenvolvidas em dois ou mais Estados;

III - cujos impactos ambientais diretos ultrapassem os limites territoriais do País ou de um ou mais Estados;

IV - destinados a pesquisar, lavrar, produzir, beneficiar, transportar, armazenar e dispor material radioativo, em qualquer estágio, ou que utilizem energia nuclear em qualquer de suas formas e aplicações, mediante parecer da Comissão Nacional de Energia Nuclear - CNEN;

52 "Art. 23. É competência comum da União, dos Estados, do Distrito Federal e dos Municípios: I - zelar pela guarda da Constituição, das leis e das instituições democráticas e conservar o patrimônio público; II - cuidar da saúde e assistência pública, da proteção e garantia das pessoas portadoras de deficiência; III - proteger os documentos, as obras e outros bens de valor histórico, artístico e cultural, os monumentos, as paisagens naturais notáveis e os sítios arqueológicos; IV - impedir a evasão, a destruição e a descaracterização de obras de arte e de outros bens de valor histórico, artístico ou cultural; V - proporcionar os meios de acesso à cultura, à educação e à ciência; VI - proteger o meio ambiente e combater a poluição em qualquer de suas formas; VII - preservar as florestas, a fauna e a flora; VIII - fomentar a produção agropecuária e organizar o abastecimento alimentar; IX - promover programas de construção de moradias e a melhoria das condições habitacionais e de saneamento básico; X - combater as causas da pobreza e os fatores de marginalização, promovendo a integração social dos setores desfavorecidos; XI registrar, acompanhar e fiscalizar as concessões de direitos de pesquisa e exploração de recursos hídricos e minerais em seus territórios; XII - estabelecer e implantar política de educação para a segurança do trânsito. Parágrafo único. Leis complementares fixarão normas para a cooperação entre a União e os Estados, o Distrito Federal e os Municípios, tendo em vista o equilíbrio do desenvolvimento e do bem-estar em âmbito nacional. (Redação dada pela Emenda Constitucional n 53 , de 2006)" 
V- bases ou empreendimentos militares, quando couber, observada a legislação específica.

$\S 1^{\circ}$ - O IBAMA fará o licenciamento de que trata este artigo após considerar o exame técnico procedido pelos órgãos ambientais dos Estados e Municípios em que se localizar a atividade ou empreendimento, bem como, quando couber, o parecer dos demais órgãos competentes da União, dos Estados, do Distrito Federal e dos Municípios, envolvidos no procedimento de licenciamento.

$\S 2^{\circ}$ - O IBAMA, ressalvada sua competência supletiva, poderá delegar aos Estados o licenciamento de atividade com significativo impacto ambiental de âmbito regional, uniformizando, quando possível, as exigências.

Além disso, o artigo $5^{\circ}$ da Resolução CONAMA 237/1997 ${ }^{53}$ estabeleceu que compete aos órgãos ambientais estaduais e do Distrito Federal, o licenciamento daqueles empreendimentos e atividades localizadas ou desenvolvidas: (a) em mais de um Município ou em unidades de conservação de domínio estadual ou do Distrito Federal; (b) nas florestas e demais formas de vegetação natural de preservação permanente relacionadas no artigo $2^{\circ}$ da Lei $\mathrm{n}^{\circ} 4.771$, de 15 de setembro de 1965 , e em todas as que assim forem consideradas por normas federais, estaduais ou municipais; (c) cujos impactos ambientais diretos ultrapassem os limites territoriais de um ou mais Municípios; (d) delegados pela União, por instrumento legal ou convênio.

Independentemente da entidade responsável pelo licenciamento, é necessário, nas hipóteses cabíveis, considerar o parecer dos demais órgãos competentes da União, dos Estados, do Distrito Federal e dos Municípios, envolvidos no procedimento de licenciamento.

\footnotetext{
53 "Art. $5^{\circ}$ - Compete ao órgão ambiental estadual ou do Distrito Federal o licenciamento ambiental dos empreendimentos e atividades: I - localizados ou desenvolvidos em mais de um Município ou em unidades de conservação de domínio estadual ou do Distrito Federal; II - localizados ou desenvolvidos nas florestas e demais formas de vegetação natural de preservação permanente relacionadas no artigo $2^{\circ}$ da Lei $n^{\circ} 4.771$, de 15 de setembro de 1965 , e em todas as que assim forem consideradas por normas federais, estaduais ou municipais; III - cujos impactos ambientais diretos ultrapassem os limites territoriais de um ou mais Municípios; IV - delegados pela União aos Estados ou ao Distrito Federal, por instrumento legal ou convênio".
} 


\subsection{O Estudo de Impacto Ambiental e seu Respectivo Relatório de Impacto Ambiental - EIA/RIMA}

Inicialmente, cumpre destacar que a Resolução CONAMA n ${ }^{\circ} 01$, de 23 de janeiro de 1986, em seu art. $1^{\circ}$, considera impacto ambiental como "qualquer alteração das propriedades físicas, químicas e biológicas do meio ambiente, causada por qualquer forma de matéria ou energia resultante das atividades humanas que direta ou indiretamente afetam: I - a saúde, a segurança e o bem-estar da população; II - as atividades sociais e econômicas; III - a biota; IV - as condições estéticas e sanitárias do meio ambiente; V - a qualidade dos recursos ambientais".

$\mathrm{O}$ artigo $2^{\circ}$ da referida Resolução ${ }^{54}$ estabelece rol exemplificativo das atividades sujeitas obrigatoriamente à elaboração do estudo de impacto ambiental para seu licenciamento, entre elas, a construção de estradas de rodagem com duas ou mais faixas de rolamento, ferrovias, oleodutos, gasodutos, minerodutos, emissários de esgotos sanitários e linhas de transmissão de energia elétrica, acima de $230 \mathrm{KV}$.

\footnotetext{
54 "Art. $2^{\text {o }}$ - Dependerá de elaboração de estudo de impacto ambiental e respectivo relatório de impacto ambiental - RIMA, a serem submetidos à aprovação do órgão estadual competente, e do IBAMA em caráter supletivo, o licenciamento de atividades modificadoras do meio ambiente, tais como: I - Estradas de rodagem com duas ou mais faixas de rolamento; II - Ferrovias; III Portos e terminais de minério, petróleo e produtos químicos; IV - Aeroportos, conforme definidos pelo inciso 1, artigo 48, do Decreto-Lei $\mathrm{n}^{\circ}$ 32, de 18.11.66; V - Oleodutos, gasodutos, minerodutos, troncos coletores e emissários de esgotos sanitários; VI - Linhas de transmissão de energia elétrica, acima de $230 \mathrm{KV}$; VII - Obras hidráulicas para exploração de recursos hídricos, tais como: barragem para fins hidrelétricos, acima de $10 \mathrm{MW}$, de saneamento ou de irrigação, abertura de canais para navegação, drenagem e irrigação, retificação de cursos d'água, abertura de barras e embocaduras, transposição de bacias, diques; VIII - Extração de combustível fóssil (petróleo, xisto, carvão); IX - Extração de minério, inclusive os da classe II, definidas no Código de Mineração; X - Aterros sanitários, processamento e destino final de resíduos tóxicos ou perigosos; XI - Usinas de geração de eletricidade, qualquer que seja a fonte de energia primária, acima de 10MW; XII - Complexo e unidades industriais e agro-industriais (petroquímicos, siderúrgicos, cloroquímicos, destilarias de álcool, hulha, extração e cultivo de recursos hídricos); XIII - Distritos industriais e zonas estritamente industriais - ZEI; XIV - Exploração econômica de madeira ou de lenha, em áreas acima de 100 hectares ou menores, quando atingir áreas significativas em termos percentuais ou de importância do ponto de vista ambiental; XV - Projetos urbanísticos, acima de 100ha. ou em áreas consideradas de relevante interesse ambiental a critério da SEMA e dos órgãos municipais e estaduais competentes; XVI - Qualquer atividade que utilize carvão vegetal, em quantidade superior a dez toneladas por dia".
} 
A Constituição de 1988 , por meio de seu artigo $225, \S 1^{\circ}$, inciso $\mathrm{IV}^{55}$, determina que o EIA/RIMA consiste em uma modalidade de avaliação de obra ou atividade capaz de desencadear significativo impacto ambiental.

Assim, pode-se dizer que o EIA/RIMA é estudo complexo cujo objetivo é fornecer ao órgão ambiental competente as informações necessárias para análise dos empreendimentos e atividades que ocasionem ou possam ocasionar relevantes impactos ao meio ambiente.

Cumpre ressaltar que o EIA/RIMA não consiste em uma defesa do empreendimento contra as normas ambientais, não se destinando, portanto, a tornar o empreendimento viável diante da legislação ambiental e exigências dos órgãos ambientais.

Em razão da complexidade e do alto custo, o citado estudo deve ser exigido somente nos casos em que se faz realmente necessário, de forma a garantir o respeito ao princípio da razoabilidade e proporcionalidade. É o órgão ambiental responsável pelo licenciamento que irá definir o tipo de estudo aplicável.

A elaboração do EIA/RIMA deve seguir os ditames dos artigos $5^{\circ} \mathrm{e}$ $6^{\circ}$ da Resolução CONAMA 01/86, que assim dispõem:

Artigo $5^{\circ}$ - $\mathrm{O}$ estudo de impacto ambiental, além de atender à legislação, em especial os princípios e objetivos expressos na Lei de Política Nacional do Meio Ambiente, obedecerá às seguintes diretrizes gerais:

I - Contemplar todas as alternativas tecnológicas e de localização de projeto, confrontando-as com a hipótese de não execução do projeto;

II - Identificar e avaliar sistematicamente os impactos ambientais gerados nas fases de implantação e operação da atividade ;

III - Definir os limites da área geográfica a ser direta ou indiretamente afetada pelos impactos, denominada área de influência do projeto, considerando, em todos os casos, a bacia hidrográfica na qual se localiza;

IV - Considerar os planos e programas governamentais, propostos e em implantação na área de influência do projeto, e sua compatibilidade.

55 "Art. 225. Todos têm direito ao meio ambiente ecologicamente equilibrado, bem de uso comum do povo e essencial à sadia qualidade de vida, impondo-se ao Poder Público e à coletividade o dever de defendê-lo e preservá-lo para as presentes e futuras gerações. $\S 1^{\circ}$ - Para assegurar a efetividade desse direito, incumbe ao Poder Público: IV - exigir, na forma da lei, para instalação de obra ou atividade potencialmente causadora de significativa degradação do meio ambiente, estudo prévio de impacto ambiental, a que se dará publicidade; (Regulamento)". 
Parágrafo Único - Ao determinar a execução do estudo de impacto ambiental o órgão estadual competente, ou o IBAMA ou, quando couber, o Município, fixará as diretrizes adicionais que, pelas peculiaridades do projeto e características ambientais da área, forem julgadas necessárias, inclusive os prazos para conclusão e análise dos estudos.

Artigo $6^{\circ}$ - $\mathrm{O}$ estudo de impacto ambiental desenvolverá, no mínimo, as seguintes atividades técnicas:

I - Diagnóstico ambiental da área de influência do projeto completa descrição e análise dos recursos ambientais e suas interações, tal como existem, de modo a caracterizar a situação ambiental da área, antes da implantação do projeto, considerando:

a) o meio físico - o subsolo, as águas, o ar e o clima, destacando os recursos minerais, a topografia, os tipos e aptidões do solo, os corpos d'água, o regime hidrológico, as correntes marinhas, as correntes atmosféricas;

b) o meio biológico e os ecossistemas naturais - a fauna e a flora, destacando as espécies indicadoras da qualidade ambiental, de valor científico e econômico, raras e ameaçadas de extinção e as áreas de preservação permanente;

c) o meio sócio-econômico - o uso e ocupação do solo, os usos da água e a sócioeconomia, destacando os sítios e monumentos arqueológicos, históricos e culturais da comunidade, as relações de dependência entre a sociedade local, os recursos ambientais e a potencial utilização futura desses recursos.

II - Análise dos impactos ambientais do projeto e de suas alternativas, através de identificação, previsão da magnitude e interpretação da importância dos prováveis impactos relevantes, discriminando: os impactos positivos e negativos (benéficos e adversos), diretos e indiretos, imediatos e a médio e longo prazos, temporários e permanentes; seu grau de reversibilidade; suas propriedades cumulativas e sinérgicas; a distribuição dos ônus e benefícios sociais.

III - Definição das medidas mitigadoras dos impactos negativos, entre elas os equipamentos de controle e sistemas de tratamento de despejos, avaliando a eficiência de cada uma delas.

IV - Elaboração do programa de acompanhamento e monitoramento (os impactos positivos e negativos, indicando os fatores e parâmetros a serem considerados.

Parágrafo Único - Ao determinar a execução do estudo de impacto Ambiental o órgão estadual competente; ou o IBAMA ou quando couber, o Município fornecerá as instruções adicionais que se fizerem necessárias, pelas peculiaridades do projeto e características ambientais da área.

É importante destacar, ainda, que a Resolução CONAMA 01/1986 determina, em seu artigo 11, a necessidade de se dar ampla publicidade ao EIA/RIMA, de forma a possibilitar a participação comunitária ${ }^{56 .}$ Vejamos o que prevê o referido dispositivo:

56 Sobre o princípio da participação comunitária, Edis Milaré elucida que "é fundamental o envolvimento do cidadão no equacionamento e implementação da política ambiental, dado que o sucesso desta supõe que todas as categorias da população e todas as forças sociais, conscientes de suas responsabilidades, contribuam para a proteção e melhoria do ambiente, que, afinal, é bem e direito de todos. Exemplo concreto de aplicação deste princípio é a garantia, estabelecida por lei, de realização de audiências públicas no curso de processos de licenciamento ambiental que demandem a realização de estudos prévios de impacto ambiental." In: MILARÉ, Edis. Direito do Ambiente. $5^{\text {a }}$ Ed., São Paulo: Revista dos Tribunais, 2007, p.776. 
Artigo 11 - Respeitado o sigilo industrial, assim solicitando e demonstrando pelo interessado o RIMA será acessível ao público. Suas cópias permanecerão à disposição dos interessados, nos centros de documentação ou bibliotecas da SEMA e do estadual de controle ambiental correspondente, inclusive o período de análise técnica,

$\S 1^{\circ}$ - Os órgãos públicos que manifestarem interesse, ou tiverem relação direta com o projeto, receberão cópia do RIMA, para conhecimento e manifestação.

$\S 2^{\circ}$ - Ao determinar a execução do estudo de impacto ambiental e apresentação do RIMA, o estadual competente ou o IBAMA ou, quando couber o Município, determinará o prazo para recebimento dos comentários a serem feitos pelos órgãos públicos e demais interessados e, sempre que julgar necessário, promoverá a realização de audiência pública para informação sobre o projeto e seus impactos ambientais e discussão do RIMA.

Em consonância com o princípio da participação comunitária, e em conformidade com o estabelecido no artigo $225, \S 1^{\circ}$, IV da Constituição Federal, o artigo $3^{\circ}$ da Resolução CONAMA 237/1997, estabelece que ao EIA/RIMA "dar-se-á publicidade, garantida a realização de audiências públicas".

Pelo exposto, conclui-se que o EIA/RIMA somente é exigível no licenciamento ambiental de empreendimentos e atividades potencialmente causadores de significativo impacto ambiental, devendo, ainda, ser dada a devida publicidade ao seu conteúdo.

Referida publicidade pode ser conferida por meio da realização de audiências públicas, solicitadas pelo órgão ambiental quando julgar necessário ou caso seja provocado por entidade civil, pelo Ministério Público ou por no mínimo 50 cidadãos, no prazo de 45 dias a contar da publicação do edital de recebimento do EIA/RIMA pelo órgão ambiental, conforme as regras estabelecidas pela Resolução CONAMA n 09/1987 ${ }^{57}$.

57 "Art. $2^{\circ}$ - Sempre que julgar necessário, ou quando for solicitado por entidade civil, pelo Ministério Público, ou por 50 (cinqüenta) ou mais cidadãos, o Órgão de Meio Ambiente promoverá a realização de audiência pública. $\S 1^{\circ}$ - O Órgão de Meio Ambiente, a partir da data do recebimento do RIMA, fixará em edital e anunciará pela imprensa local a abertura do prazo que será no mínimo de 45 dias para solicitação de audiência pública. $\S 2^{\circ}$ - No caso de haver solicitação de audiência pública e na hipótese do Órgão Estadual não realizá-la, a licença concedida não terá validade. $\S 3^{\circ}$ - Após este prazo, a convocação será feita pelo Órgão Licenciador, através de correspondência registrada aos solicitantes e da divulgação em órgãos da imprensa local. $\S 4^{\circ}$ - A audiência pública deverá ocorrer em local acessível aos interessados. $\S 5^{\circ}$ Em função da 1ocalização geográfica dos solicitantes, e da complexidade do tema, poderá haver mais de uma audiência pública sobre o mesmo projeto de respectivo Relatório de Impacto Ambiental - RIMA". 
A realização de audiência pública tem por finalidade expor aos interessados o conteúdo do projeto e dos possíveis impactos ambientais, bem como, esclarecer eventuais dúvidas e questionamentos que possam surgir ao longo da apresentação, devendo ser realizada em local e horário acessíveis de forma a garantir ampla participação da população.

Ante o exposto no presente capítulo, verifica-se que o licenciamento ambiental é imprescindível para o desenvolvimento sustentável, visando à proteção do meio ambiente por meio de imposição de restrições e exigências que permitam a mitigação dos impactos ambientais das atividades efetiva ou potencialmente causadoras de degradação ao meio ambiente.

Sendo assim, dúvida não há de que é necessário o licenciamento ambiental de atividades efetiva ou potencialmente causadoras de impactos em terras indígenas ou em seu entorno, observadas suas peculiaridades. É o que se passa a analisar. 


\section{O COMPONENTE INDÍGENA NO LICENCIAMENTO AMBIENTAL}

Como visto, o licenciamento ambiental constitui instrumento apto a evitar a degradação ambiental, eis que consiste no controle prévio, pelo Poder Público, de atividades que possam causar danos ao meio ambiente, por meio da imposição de restrições, condições e exigências para o regular exercício destas atividades.

Por sua vez, o procedimento administrativo demarcatório, apesar de ser meramente declaratório eis que o direito dos índios de habitar suas terras e delas usufruir é anterior ao reconhecimento formal pelo Poder Público, é imprescindível para a produção dos efeitos fáticos e jurídicos a ele relacionados.

Contudo, a demarcação das terras indígenas existentes no país ainda não foi concluída pelo Poder Público, o que acarreta em grande insegurança jurídica tendo em vista que a eventual identificação e delimitação de determinada terra indígena, ainda que em área não sobreposta, mas contínua ou próxima, a qualquer empreendimento, impacta seu licenciamento ambiental, ainda que já instalado.

Isto posto, passemos à questão central do presente trabalho com a análise do licenciamento ambiental de empreendimentos e atividades localizadas em terras indígenas já demarcadas ou ainda não identificadas.

\subsection{O Papel da Funai no Licenciamento Ambiental}

\subsubsection{Consulta Prévia à Funai}

O licenciamento ambiental de atividades que causem significativo impacto ambiental em terras indígenas é de competência do IBAMA, nos termos do artigo $4^{\circ}$, I da Resolução CONAMA n ${ }^{\circ} 237 / 97^{58}$.

\footnotetext{
$58 \quad$ "Art. $4^{\text {o }}$ - Compete ao Instituto Brasileiro do Meio Ambiente e dos Recursos Naturais Renováveis - IBAMA, órgão executor do SISNAMA, o licenciamento ambiental, a que se refere o artigo 10 da Lei $\mathrm{n}^{\circ}$ 6.938, de 31 de agosto de 1981, de empreendimentos e atividades com significativo impacto ambiental de âmbito nacional ou regional, a saber: I - localizadas ou desenvolvidas conjuntamente no Brasil e em país limítrofe; no mar territorial; na plataforma continental; na zona econômica exclusiva; em terras indígenas ou em unidades de conservação do domínio da União".
} 
A Instrução Normativa IBAMA n 184, de 17 de julho de 2008, estabelece, em seu artigo $19^{59}$, que o IBAMA deverá orientar o empreendedor quanto à distribuição do EIA aos órgãos intervenientes. Em seguida, no artigo $21^{60}$, determina que os órgãos envolvidos no licenciamento deverão se posicionar sobre o EIA em 60 dias, devendo a FUNAI identificar e se manifestar sobre possíveis impactos em comunidades indígenas e se as medidas propostas no EIA são suficientes para mitigais tais impactos.

Assim, tanto a FUNAI quanto os demais órgãos envolvidos no licenciamento ambiental, como, por exemplo, a Fundação Palmares e o Instituto do Patrimônio Histórico e Artístico Nacional - IPHAN, são consultados pelo IBAMA previamente à emissão da licença prévia.

Cumpre ressaltar que esta é uma fase preliminar no licenciamento, na qual é verificada e aprovada a viabilidade ambiental do empreendimento sem, contudo, autorizar o início das obras. Nesta fase, são identificados os aspectos que precisam ser aprofundados e detalhados pelo empreendedor para a posterior emissão da licença de instalação.

59 "Art. 19. O Ibama orientará o empreendedor quanto a distribuição do estudo ambiental. § $1^{\circ}$ O EIA/RIMA, o EIA será distribuído aos órgãos federais intervenientes e aos OEMAs e OMMAs envolvidos, e o RIMA será disponibilizado no site do Ibama/Licenciamento, nas Superintendências Estaduais do Ibama envolvidas, no Centro Nacional de Informações Ambientais - CNIA do Ibama e nas sedes municipais envolvidas. $§ 2^{\circ} \mathrm{O}$ empreendedor deverá providenciar o envio ao Ibama/DILIC de comprovante de entrega do EIA e do RIMA aos seus destinatários".

60 "Art. 21. Aos órgãos envolvidos no licenciamento será solicitado posicionamento sobre o estudo ambiental em 60 dias e no que segue: OEMAs envolvidas - avaliar o projeto, seus impactos e medidas de controle e mitigadoras, em consonância com plano, programas e leis estaduais; Unidade de conservação - identificar e informar se existe restrições para implantação e operação do empreendimento, de acordo com o Decreto de criação, do plano de manejo ou zoneamento; FUNAI e Fundação Palmares - identificar e informar possíveis imapctos sobre comunidades indígenas e quilombolas e, se as medidas propostas para mitigar os impactos são eficientes; IPHAN - informar se na área pretendida já existe sítios arqueológicos identificados e, se as propostas apresentadas para resgate são adequadas. $\S 1^{\circ}$ Os OEMAs intervenientes deverão se manifestar em 30 dias após a entrega do estudo, a não manifestação será registrada como aprovação das conclusões e sugestões do estudo ambiental. $\S 2^{\circ}$ Os órgãos intervenientes deverão se manifestar em 30 dias após a entrega do estudo, a não manifestação será convertida em condicionante da licença prévia, neste caso a licença de instalação não será emitida até a definitiva manifestação dos órgãos federais intervenientes". 


\subsubsection{FUNAI: Órgão Integrante do SISNAMA}

$\mathrm{O}$ artigo $6^{\circ}$ da já mencionada Lei $\mathrm{n}^{\circ}$ 6.938/81, abaixo transcrito, criou o Sistema Nacional do Meio Ambiente - SISNAMA, constituído por diversos órgãos da Administração Pública:

Art $6^{\circ}$ - Os órgãos e entidades da União, dos Estados, do Distrito Federal, dos Territórios e dos Municípios, bem como as fundações instituídas pelo Poder Público, responsáveis pela proteção e melhoria da qualidade ambiental, constituirão o Sistema Nacional do Meio Ambiente - SISNAMA, assim estruturado:

I - Órgão Superior: o Conselho Nacional do Meio Ambiente - CONAMA, com a função de assistir o Presidente da República na formulação de diretrizes da Política Nacional do Meio Ambiente;

II - Órgão Central: a Secretaria Especial do Meio Ambiente - SEMA, do Ministério do Interior, à qual cabe promover, disciplinar e avaliar a implantação da Política Nacional do Meio Ambiente;

III - Órgãos Setoriais: os órgãos ou entidades integrantes da Administração Pública Federal, direta ou indireta, bem como as fundações instituídas pelo Poder Público, cujas entidades estejam, total ou parcialmente, associadas às de preservação da qualidade ambiental ou de disciplinamento do uso de recursos ambientais;

IV - Órgãos Seccionais: os órgãos ou entidades estaduais responsáveis pela execução de programas e projetos e de controle e fiscalização das atividades suscetíveis de degradarem a qualidade ambiental;

V - Órgãos Locais: os órgãos ou entidades municipais responsáveis pelo controle e fiscalização dessas atividades, nas suas respectivas áreas de jurisdição.

Pela leitura do referido dispositivo, resta claro que a FUNAI se enquadra como órgão setorial do SISNAMA, eis que é a responsável por garantir a posse permanente das terras indígenas bem como o usufruto exclusivo dos recursos naturais e de todas as utilidades nelas existentes, conforme estabelecido pela Lei ${ }^{\circ} 5.371$, de 05 de dezembro de 1967.

Neste sentido, Luiz Fernando Villares ${ }^{61}$ nos ensina que:

(...) a Funai é órgão do Sistema Nacional do Meio Ambiente - Sisnama competente para disciplinar o uso dos recursos ambientais nas terras indígenas, respeitando sempre a organização social, costumes, línguas, crenças e tradições indígenas.

61 VILLARES, Luiz Fernando. Direito e Povos Indígenas. Curitiba: Ed. Juruá, 2009. p. 224 
A Lei $\mathrm{n}^{\circ} 5.371 / 67$, em seu artigo $1^{\circ}$, inciso $\mathrm{VII}^{62}$, conferiu a essa Fundação, o poder de polícia administrativo, de forma a garantir sua plena atuação na defesa dos interesses indígenas.

Considerando que a FUNAI se enquadra como órgão setorial, integrante do SISNAMA, verifica-se que estão à sua disposição, para defesa dos interesses indígenas, (i) a avaliação de impacto ambiental e (ii) o licenciamento e revisão de atividades efetiva ou potencialmente poluidoras, ambos instrumentos da Política Nacional do Meio Ambiente.

Diante do exposto, pode-se inferir que todas as atividades de relevante impacto ambiental são passíveis de análise pela FUNAI, desde que acarretem ou possam acarretar impacto em terras indígenas.

62 "Art. $1^{\circ}$ Fica o Governo Federal autorizado a instituir uma fundação, com patrimônio próprio e personalidade jurídica de direito privado, nos termos da lei civil, denominada "Fundação Nacional do Índio", com as seguintes finalidades: VII - exercitar o poder de polícia nas áreas reservadas e nas matérias atinentes à proteção do índio". 


\subsection{Estudos do Componente Indígena}

\subsubsection{Parte Integrante do Diagnóstico Socioeconômico}

Inicialmente, cumpre ressaltar que o diagnóstico socioeconômico integra o diagnóstico ambiental, nos termos do artigo $6^{\circ}$ da Resolução CONAMA $01 / 86^{63}$.

Conforme o disposto no item anterior, verifica-se que a participação da FUNAI no licenciamento ambiental se dá, essencialmente, pela combinação da legislação ambiental com a legislação indigenista brasileira, de forma a garantir o interesse dos povos indígenas.

Para tanto, deve-se analisar os estudos do componente indígena, os quais constituem parte indissociável dos estudos de impacto ambiental, fazendo parte da análise sócio-econômica do processo de licenciamento ambiental.

\footnotetext{
63 "Art. $6^{\circ}$ - O estudo de impacto ambiental desenvolverá, no mínimo, as seguintes atividades técnicas: I - Diagnóstico ambiental da área de influência do projeto completa descrição e análise dos recursos ambientais e suas interações, tal como existem, de modo a caracterizar a situação ambiental da área, antes da implantação do projeto, considerando: a) o meio físico - o subsolo, as águas, o ar e o clima, destacando os recursos minerais, a topografia, os tipos e aptidões do solo, os corpos d'água, o regime hidrológico, as correntes marinhas, as correntes atmosféricas; b) o meio biológico e os ecossistemas naturais - a fauna e a flora, destacando as espécies indicadoras da qualidade ambiental, de valor científico e econômico, raras e ameaçadas de extinção e as áreas de preservação permanente; c) o meio sócio-econômico - o uso e ocupação do solo, os usos da água e a sócio-economia, destacando os sítios e monumentos arqueológicos, históricos e culturais da comunidade, as relaç̃es de dependência entre a sociedade local, os recursos ambientais e a potencial utilizacão futura desses recursos. II - Análise dos impactos ambientais do projeto e de suas alternativas, através de identificação, previsão da magnitude e interpretação da importância dos prováveis impactos relevantes, discriminando: os impactos positivos e negativos (benéficos e adversos), diretos e indiretos, imediatos e a médio e longo prazos, temporários e permanentes; seu grau de reversibilidade; suas propriedades cumulativas e sinérgicas; a distribuição dos ônus e benefícios sociais. III - Definição das medidas mitigadoras dos impactos negativos, entre elas os equipamentos de controle e sistemas de tratamento de despejos, avaliando a eficiência de cada uma delas. IV - Elaboração do programa de acompanhamento e monitoramento (os impactos positivos e negativos, indicando os fatores e parâmetros a serem considerados. Parágrafo Único - Ao determinar a execução do estudo de impacto Ambiental o órgão estadual competente; ou o IBAMA ou quando couber, o Município fornecerá as instruções adicionais que se fizerem necessárias, pelas peculiaridades do projeto e características ambientais da área".
} 
Isto porque, ao analisar o meio socioeconômico da área de influência do projeto, considerando o uso e ocupação do solo, os usos da água e a sócio-economia, destacando sítios e monumentos arqueológicos, históricos e culturais da comunidade, as relações de dependência entre a sociedade local, os recursos ambientais e a potencial utilização futura desses recursos, o empreendedor necessariamente identificará a presença de comunidades indígenas, estudando suas especificidades e as possíveis ações a serem adotadas a fim de mitigar os impactos a serem causados, caso o empreendimento cause impactos em determinada terra indígena.

Importante destacar que os impactos sócio-culturais são tão importantes quanto os ambientais devendo, ambos, serem tratados de maneira articulada e integrada.

\subsubsection{Ausência de Legislação Específica}

No tocante às questões indígenas, é certo que a Constituição Federal define com clareza a terra indígena e o dever de proteção desta, entretanto, ainda há carência de legislação que regule e determine a fiscalização das terras indígenas e seu uso.

Sendo assim, não há previsão específica do procedimento a ser adotado quanto à análise do componente indígena, nem do momento em que a FUNAI deve ingressar no processo de licenciamento.

Em razão da ausência de legislação específica, o Presidente da FUNAI, em 2007, editou a Instrução Normativa $n^{\circ}$ 002, de 21 de março de 2007, a qual estabeleceu normas acerca da participação da FUNAI no processo de licenciamento ambiental de empreendimentos ou atividades potencialmente causadoras de impacto no meio ambiente das Terras Indígenas, na cultura e povos indígenas. 
Referida instrução normativa previu com clareza os procedimentos a serem adotados por essa Fundação, inclusive no que diz respeito ao termo de referência para elaboração do componente indígena do EIA, o qual contaria com a participação das comunidades indígenas potencialmente afetadas.

Contudo, em razão da ausência de consulta aos órgãos envolvidos no processo de licenciamento ambiental de obras e empreendimentos que afetem povos e Terras Indígenas sobre a edição da referida Instrução Normativa, esta foi revogada pela Instrução Normativa do Presidente da FUNAI n ${ }^{\circ} 003$, de 27 de abril de 2007.

O Estatuto do Índio, por sua vez, também é omisso com relação ao tema e há aproximadamente dezenove anos tramita no Congresso Nacional projeto de revisão legislativa do referido estatuto, o PL n ${ }^{\circ}$ 2057/1991, que ainda está pendente de aprovação.

\subsubsection{O Que vem sendo Exigido}

Primeiramente, é importante destacar que as informações constantes deste item foram retiradas das atas de reunião ordinária dos membros da Comissão Nacional da Política Indigenista - $\mathrm{CNPI}^{64}$, bem como do parecer técnico da FUNAI quando da análise do componente indígena do EIA/RIMA da Usina Hidrelétrica de Belo Monte ${ }^{65}$.

Com a ausência de legislação específica sobre o tema, a FUNAI e o IBAMA têm atuado em conjunto de forma a evitar eventuais danos aos direitos constitucionalmente conferidos aos índios, utilizando-se, inclusive, por analogia, de dispositivos legais aplicados às unidades de conservação.

\footnotetext{
64 Disponível em <http://funai.gov.br/ultimas/CNPI/atas>. Acesso em 25 out. 2010.

65 Disponível em <http://www.socioambiental.org/banco_imagens/pdfs/BeloMonteFUNAI.pdf $>$. Acesso em 20 out. 2010
} 
Desta forma, a FUNAI tem participado do licenciamento desde o momento de requerimento do termo de referência pelo empreendedor para a realização dos estudos ambientais necessários.

Neste sentido, a FUNAI encaminha ao IBAMA um Termo de Referência cujo objetivo é orientar a elaboração do EIA/RIMA especificamente no que diz respeito às terras e povos indígenas afetados pelo empreendimento. O resultado destes estudos visa a subsidiar a proposição de ações de mitigação e compensação adequadas àquelas comunidades específicas.

Para tanto, é necessária a contextualização da área de influência do empreendimento com relação aos povos e terras indígenas, baseada nas peculiaridades técnicas da obra e das respectivas comunidades afetadas. Neste momento requer-se a caracterização o empreendimento, a região de localização, bioma, sensibilidade, distância entre pontos estratégicos, grau de entropização e, especificamente em relação aos povos indígenas, a interação com a sociedade envolvente e com outros povos indígenas, a territorialidade e o uso dos recursos naturais.

Assim, os estudos do componente indígena devem conter, basicamente, (i) caracterização físico-biótica das terras indígenas; (ii) caracterização e análise do modo de vida dos grupos indígenas com ênfase na importância dos recursos hídricos e vegetação/fauna relacionados; (iii) análise da relação sócio-política, econômica e cultural dos grupos indígenas com a sociedade envolvente e com outros grupos indígenas; e (iv) identificação e análise dos possíveis impactos decorrentes da instalação e operação do empreendimento.

É importante destacar que as ações voltadas à proteção ambiental das terras indígenas e seu entorno destinam-se a garantir a manutenção do equilíbrio necessário à sobrevivência física e cultural das comunidades indígenas devendo contemplar, de acordo com o artigo $9^{\circ}$ do Decreto 
$\mathrm{n}^{\mathrm{o}} 1.141$, de 5 de maio de $1994^{66}$ (dispõe sobre as ações de proteção ambiental, saúde e apoio às atividades produtivas para as comunidades indígenas), o controle ambiental das atividades potencial ou efetivamente modificadoras do meio ambiente, ainda que desenvolvidas no entorno das Terras Indígenas.

Vale ressaltar que os pontos que norteiam a atuação da FUNAI no licenciamento ambiental são os seguintes: (i) direitos territoriais especiais reconhecidos constitucionalmente; (ii) direto à informação e ao consentimento livre e prévio com relação às políticas públicas e aos empreendimentos que possam afetar a integridade dos recursos naturais das terras indígenas; (iii) o direito às diferenças culturais; (iv) respeito à autonomia dos povos indígenas; e (v) proteção territorial e ambiental das terras indígenas.

No caso do licenciamento da Usina Hidrelétrica Belo Monte, no Rio Xingu, com a solicitação do Ibama para a emissão do Termo de Referência específico para o componente indígena, a equipe técnica da Funai, levando em consideração todos os encaminhamentos feitos até então sobre o empreendimento, adotou uma classificação mais dinâmica para a realização destes estudos, considerando, entre outros fatores (i) o histórico do processo, (ii) a área de abrangência do projeto, (iii) outros empreendimentos na região e seus estudos, (iv) as etnias presentes e a pressão regional sobre as terras indígenas.

Para tanto, um dos procedimentos adotados pela FUNAI foi a consulta às comunidades indígenas, principalmente aquelas diretamente

\footnotetext{
66 "Art. $9^{\circ}$ As ações voltadas à proteção ambiental das terras indígenas e seu entorno destinam-se a garantir a manutenção do equilíbrio necessário à sobrevivência física e cultural das comunidades indígenas, contemplando: I - diagnóstico ambiental, para conhecimento da situação, como base para as intervenções necessárias; II - acompanhamento e controle da recuperação das áreas que tenham sofrido processo de degradação de seus recursos naturais; III - controle ambiental das atividades potencial ou efetivamente modificadoras do meio ambiente, mesmo aquelas desenvolvidas fora dos limites das terras indígenas que afetam; IV - educação ambiental, dirigida às comunidades indígenas e à sociedade envolvente, visando à participação na proteção do meio ambiente nas terras indígenas e seu entorno; V - identificação e difusão de tecnologias indígenas e não-indígenas, consideradas apropriadas do ponto de vista ambiental e antropológico".
} 
impactadas pelos empreendimentos. Assim, por meio de reuniões específicas, procurou-se levar a informação para as comunidades indígenas de modo a orientar o processo e dar subsídios para que elas possam se posicionar sobre o empreendimento e seus impactos, garantindo que uma efetiva participação das referidas comunidades.

Por fim, a FUNAI é responsável acompanhar todas as fases do licenciamento do empreendimento, incluindo novas oitivas com a eventual participação de outros órgãos públicos, elaboração e implementação de PBA, avaliação de programas, entre outros.

\subsection{Licenciamento de Empreendimentos com Impactos em Terras Indígenas}

\subsubsection{Terras Indígenas já Demarcadas}

Conforme exposto neste trabalho, não há dúvidas que os índios têm direito originário às terras que ocupam tradicionalmente, direito esse que é anterior e oponível a qualquer reconhecimento ou ocupação superveniente.

Nesse sentido, Raimundo Sérgio Barros Leitão ${ }^{67}$ esclarece:

A demarcação de uma terra indígena, fruto do reconhecimento feito pelo Estado, portanto, é ato meramente declaratório, cujo objetivo é simplesmente precisar a real extensão da posse para assegurar a plena eficácia do dispositivo constitucional, que impõe ao Estado a obrigação de protegê-la.

Destarte, as determinações legais existentes são, por si só, suficientes para garantir o reconhecimento dos direitos indígenas sobre as terras tradicionalmente ocupadas pelos índios, independentemente da sua demarcação física.

67 LEITÃO, Raimundo Sérgio Barros. Natureza jurídica do ato administrativo de reconhecimento de terra indígena - a declaração em juízo. In: SANTILLI, Juliana (Coord.). Os direitos indígenas e a Constituição. Porto Alegre: SAFE / Núcleo de Direitos Indígenas, 1993, p. 67. 
Contudo, a demarcação é imprescindível para a produção dos efeitos fáticos e jurídicos a ele relacionados, visando a conferir segurança jurídica, no sentido de fixar contornos territoriais.

Além disso, ao longo deste trabalho, restou irrefutável o direito dos índios ao usufruto exclusivo de suas terras de forma ampla e irrestrita. No entanto, recentemente, o Supremo Tribunal Federal ao julgar o caso da Terra Indígena Raposa Serra do Sol entendeu que tal exclusividade é conciliável com a eventual presença de não-índios, bem como com a instalação de determinados equipamentos, como se depreende do seguinte trecho do voto proferido pelo Ministro Carlos Ayres de Brito ${ }^{68}$ :

\begin{abstract}
A conciliação entre terras indígenas e a visita de não-índios, tanto quanto com a abertura de vias de comunicação e a montagem de bases físicas para a prestação de serviços públicos ou de relevância pública 83 . Não se pense, contudo, que a exclusividade de usufruto das riquezas do solo, dos rios e dos lagos das terras indígenas seja inconciliável com a eventual presença de nãoíndios, bem assim com a instalação de equipamentos tecnológicos, a abertura de estradas e outras vias de comunicação, a montagem ou construção de bases físicas para a prestação de serviços públicos ou de relevância pública. A conciliação das coisas é possível, reafirme-se, desde que tudo se processe debaixo da liderança institucional da União, controle do Ministério Público e atuação coadjuvante de entidades tanto da Administração Federal quanto representativa dos próprios indígenas.
\end{abstract}

No que diz respeito à exploração e ao aproveitamento de recursos hídricos, incluídos os potenciais energéticos, e a pesquisa e lavra de riquezas minerais, em terras indígenas, faz-se mister destacar que é de competência do Congresso Nacional autorizar tais atividades, desde que ouvidas as comunidades afetadas, de acordo com o disposto no artigo 231, $\S 3^{\circ}$ da Constituição Federal ${ }^{69}$.

\footnotetext{
68 STF. Pet. 3388. Rel. Min. Carlos Ayres de Britto, Brasília, 19 mar. 2009.

69 "Art. 231. São reconhecidos aos índios sua organização social, costumes, línguas, crenças e tradições, e os direitos originários sobre as terras que tradicionalmente ocupam, competindo à União demarcá-las, proteger e fazer respeitar todos os seus bens. $\$ 3^{\circ} \mathrm{O}$ aproveitamento dos recursos hídricos, incluídos os potenciais energéticos, a pesquisa e a lavra das riquezas minerais em terras indígenas só podem ser efetivados com autorização do Congresso Nacional, ouvidas as comunidades afetadas, ficando-lhes asseguradas participação nos resultados da lavra, na forma da ler".
} 
$\mathrm{O}$ art. $231, \S 5^{\circ}$ da Constituição Federal ${ }^{70}$ prevê a remoção de grupos indígenas desde que haja interesse da soberania nacional, mediante aprovação do Congresso Nacional, hipótese na qual poderiam incluir-se determinadas obras de infra-estrutura. Contudo, os casos de soberania nacional ainda não foram regulamentados, razão pela qual não há que se falar em aproveitamento das terras indígenas neste sentido.

Assim, a instalação de empreendimentos em determinada terra indígena, ou em áreas contínuas ou próximas a ela, pode gerar reflexos como a proibição de sua instalação na área considerada como terra indígena ou a incorporação do componente indígena nos estudos ambientais e sociais do licenciamento, além de novas responsabilidades de caráter ambiental e social aos empreendedores.

Desta forma, a FUNAI deverá exigir no licenciamento ambiental uma avaliação profunda acerca dos impactos nas terras indígenas, elaborando inclusive termo de referência a ser observado pelos empreendedores quando da elaboração dos estudos ambientais.

Outro ponto a ser destacado é o da exigência constante do artigo 17 da Convenção 169 da OIT, que estabelece a necessidade de oitiva prévia da comunidade indígena potencialmente afetada ao se iniciar o processo de licenciamento ambiental, conforme abaixo:

Art. 17.

2. Os povos interessados deverão ser consultados sempre que for considerada sua capacidade para alocarem suas terras ou transmitirem de outra forma os seus direitos sobre estas terras para fora de sua comunidade.

Com efeito, ainda não há previsão específica no ordenamento jurídico brasileiro sobre a informação dos povos indígenas nos processos de

70 "Art. 231. São reconhecidos aos índios sua organização social, costumes, línguas, crenças e tradições, e os direitos originários sobre as terras que tradicionalmente ocupam, competindo à União demarcá-las, proteger e fazer respeitar todos os seus bens. § $5^{\circ}$ - É vedada a remoção dos grupos indígenas de suas terras, salvo, "ad referendum" do Congresso Nacional, em caso de catástrofe ou epidemia que ponha em risco sua população, ou no interesse da soberania do País, após deliberação do Congresso Nacional, garantido, em qualquer hipótese, o retorno imediato logo que cesse o risco". 
licenciamento ambiental. Contudo, é importante respeitar tal exigência, observando inclusive o princípio da participação comunitária, de forma a evitar eventuais conflitos com os povos indígenas a serem potencialmente afetados.

A consulta prévia implica a possibilidade dos povos interessados de discutirem prioridades de desenvolvimento econômico e social das regiões nas quais estão inseridos e que influenciam o futuro de suas terras, visando, portanto, a ser um instrumento de participação e influência efetiva dos povos sobre as opções de desenvolvimento econômico e social das regiões e países que compartilham.

No âmbito da América Latina, importa destacar a recente decisão da Corte Interamericana de Direitos Humanos que, em 28 de novembro de 2007, condenou o Suriname por desconhecer direitos fundamentais do povo tribal Saramaka, na aprovação da construção de uma hidrelétrica que afeta suas terras tradicionais. Dentre os principais argumentos trazidos na decisão, encontra-se a ofensa ao direito de consulta prévia sobre medidas administrativas para efeitos de autorização e construção da obra em território Saramaka ${ }^{71}$

Diante de todo o exposto, conclui-se que consiste dever da FUNAI participar efetivamente dos processos de licenciamento ambiental de obras ou atividades potencial ou efetivamente causadoras de degradação do meio ambiente em terras indígenas, exigindo estudo de impacto sócio-ambiental ou avaliações de impacto específicas às populações e terras indígenas afetadas.

Sendo assim, em quaisquer processos de licenciamento nos quais haja impacto nas comunidades indígenas ou em suas terras, os órgãos ambientais devem consultar previamente a FUNAI para que esta elabore requisitos específicos a serem considerados nos estudos ambientais.

\footnotetext{
71 Disponível em <http://www.socioambiental.org/inst/esp/consulta_previa/?q=node/28>
} Acesso em 18 out 2010. 
Por fim, há que se ressaltar a importância do controle pela União (que tem o dever constitucional de demarcar, proteger e fazer respeitar todos os bens situados em terras indígenas) sobre os Estados e Municípios, sempre que estes atuarem no interior das terras já demarcadas como indígenas. Isto porque, geralmente, Estados e Municípios vêem as áreas indígenas como mutilação de seus territórios, sendo, portanto, um obstáculo ao desenvolvimento econômico.

\subsubsection{Terras Indígenas ainda não Identificadas}

O ADCT estabeleceu, em seu artigo $67^{72}$, o prazo de cinco anos, a contar da promulgação da Constituição Federal, para a conclusão pela União da demarcação de todas as terras indígenas.

Restou, assim, consagrada a urgência e essencialidade do processo demarcatório das terras indígenas.

Não obstante a relevância e urgência da matéria, o prazo previsto no ADCT está longe de ser cumprido pelo Poder Público, o que, por si só, gera imensa insegurança jurídica não só para os empreendedores como também para os entes federados interessados em promover o desenvolvimento em suas regiões.

Por outro lado, como amplamente demonstrado, o processo demarcatório é meramente declaratório. Caso assim não fosse, diversos povos indígenas já teriam sido retirados de suas terras, até porque a FUNAI, órgão responsável pela demarcação das terras indígenas, não possui recursos suficientes para atender à crescente demanda dos povos indígenas pela demarcação de suas terras.

É importante mencionar que o crescimento da demanda dos povos indígenas pela demarcação de suas terras pode ser justificado pela

\footnotetext{
72 "Art. 67 - A União concluirá a demarcação das terras indígenas no prazo de cinco anos a partir da promulgação da Constituição".
} 
implantação de empreendimentos em áreas consideradas terras indígenas, porém, ainda não reconhecidas formalmente.

Desta forma, dúvida não há de que o licenciamento de empreendimentos passíveis de causar impactos em terras indígenas ainda não identificadas são os casos mais sensíveis e delicados.

Neste sentido, pode-se citar como exemplo o recente conflito indígena no Estado do Ceará $^{73}$, no que diz respeito à implantação do Complexo Industrial e Portuário do Pecém - CIPP, nos Municípios de Caucaia e São Gonçalo de Amarante, em supostas terras tradicionalmente ocupadas pelos índios Anacés.

No referido caso, a idéia de implantação do projeto remonta ao ano de 1996, quando foi declarada a utilidade pública da área onde será implantado o CIPP, o qual consiste no maior projeto de desenvolvimento do Estado, mediante a construção de um porto, de usinas siderúrgicas, usinas geradoras de energia elétrica, refinarias de petróleo, entre outras.

O licenciamento ambiental do CIPP foi conduzido pelo IBAMA e, após mais de uma década de estudos ambientais, o Ministério Público Federal - MPF ajuizou duas Ações Civis Públicas, com pedido liminar, objetivando a paralisação das obras dos empreendimentos a serem instalados no CIPP, com o intuito de proteger direitos e interesses coletivos relacionados à comunidade indígena Anacé, buscando-se, assim, evitar a desapropriação e o reassentamento do grupo étnico do seu território tradicional.

Os pedidos liminares requeridos pelo MPF foram negados pelo juiz de $1^{a}$ instância, sendo tais decisões mantidas em segunda instância.

Em julho do presente ano, foi instituído grupo técnico pela FUNAI, por meio da Portaria ${ }^{\circ} 1.035$ do Presidente da FUNAI, com a atribuição de identificar e delimitar a terra indígena Anacé.

\footnotetext{
73 Informações obtidas na cópia dos autos das Ações Civis Públicas n 2009.81.00.016918-2 e n ${ }^{\circ}$ 0002218-23.2010.4.05.8100, ambas em trâmite perante a 10ª Vara Federal do Estado do Ceará.
} 
Enquanto não se define sobre a ocupação territorial indígena pela FUNAI, sua extensão e limites, o licenciamento ambiental e instalação dos empreendimentos prosseguem sem obstáculos, sem nenhuma decisão judicial que os impeça.

Considerando que a demarcação das terras indígenas é contínua, de forma a garantir o peculiar regime constitucional das terras indígenas, as plantas industriais já instaladas e em operação, se não excluídas da proposta de demarcação administrativa, constituem obstáculos significativos ao reconhecimento da terra indígena. 


\section{CONCLUSÃO}

Pelo que foi demonstrado no presente estudo, nota-se que atualmente não há previsão específica na legislação brasileira acerca do procedimento a ser adotado para o licenciamento de empreendimentos passíveis de causar impactos em terras indígenas, ainda que localizados em seu entorno. Assim, não está claramente definido no ordenamento jurídico brasileiro qual o tipo de autorização deve ser concedida pela FUNAI para a instalação de empreendimentos com impactos em terras indígenas, nem há esclarecimentos com relação à participação indígena no licenciamento de referidos empreendimentos.

Além disso, há que se analisar o momento de consulta à FUNAI definido na instrução normativa do IBAMA no 184/2008. Como já estudado, a fase de emissão da licença prévia consiste em fase muito preliminar do licenciamento, na qual as informações acerca do empreendimento a ser desenvolvido são muito superficiais, havendo, inclusive, muitos casos de alteração do projeto quando do detalhamento dos estudos técnicos e ambientais, bem como de alteração do local de implantação.

Neste sentido, o ideal seria que a FUNAI se manifestasse antes da implantação do empreendimento, ou seja, antes da concessão da licença de instalação, ocasião em que terá maiores subsídios para analisar efetivamente os impactos nas terras indígenas. Sendo assim, a consulta à FUNAI constaria como condicionante da licença prévia, para obtenção da licença de instalação.

A título de exemplo, vale mencionar o licenciamento ambiental da Colômbia, no qual há obrigação específica de consulta prévia aos índios como condição para instauração do processo de licenciamento, conforme previsto no Decreto 1320, de 1998, do Ministério do Interior. 
Pelo exposto, conclui-se ser necessária e urgente uma reforma legislativa de forma a prever claramente o procedimento a ser adotado para a efetiva participação da FUNAI no licenciamento ambiental de empreendimentos passíveis de causar impactos em terras indígenas, de forma a garantir a defesa dos interesses das comunidades afetadas. 


\section{BIBLIOGRAFIA}

ANTUNES, Paulo de Bessa. Ação Civil Pública, Meio Ambiente e Terras Indígenas. Rio de Janeiro: Lumen Juris, 1998. 187p.

. Federalismo e Competências Ambientais

no Brasil. 11ª Ed. Rio de Janeiro: Lúmen Júris, 2007. 334p.

. Direito Ambiental. 9 ${ }^{\mathrm{a}}$ Ed. Rio de Janeiro:

Lúmen Júris, 2007. 988p.

CUNHA, Manuela Carneiro da (org.). Legislação indigenista no Século XIX: Uma compilação: 1808-1889. São Paulo: EDUSP: Comissão PróÍndio de São Paulo, 1992. 362p.

FARIAS, Paulo José Leite. Competência Federativa e Proteção Ambiental. Porto Alegre: Sergio Antonio Fabris Editor, 1999. 444p.

LEITÃO, Raimundo Sérgio Barros. Natureza jurídica do ato administrativo de reconhecimento de terra indígena - a declaração em juízo. In: SANTILLI, Juliana (Coord.). Os direitos indígenas e a Constituição. Porto Alegre: SAFE / Núcleo de Direitos Indígenas, 1993. 312p.

MILARÉ, Edis. Direito do Ambiente. 5 ${ }^{\mathrm{a}}$ Ed., São Paulo: Revista dos Tribunais, 2007. 1280p.

MIRANDA, Pontes de. Comentários à Constituição da República dos Estados Unidos do Brasil. Rio de Janeiro: Editora Guanabara Waissmann, Koogan, Ltda. Tomo II.

Comentários à Constituição de 1946, vol. V, 1953.

TOURINHO NETO, Fernando da Costa. "Os direitos originários dos indios sobre as terras que ocupam e suas conseqüências jurídicas", in 
SANTILLI, Juliana. Os direitos indígenas e a Constituição. Porto Alegre: NDI e Fabris, 1993. 312p.

TRIBUNAL REGIONAL FEDERAL DA PRIMEIRA REGIÃO, Jurisprudência. Disponível em <www.trf1.jus.br>

SILVA, José Afonso da. Curso de Direito Constitucional. São Paulo: Malheiros, 2004. $5^{\mathrm{a}}$ edição.

SUPREMO TRIBUNAL FEDERAL. Jurisprudência. Disponível em <www.stf.jus.br>

VILLARES, Luiz Fernando. Direito e Povos Indígenas. Curitiba: Ed. Juruá, 2009. 350p.

Informação $\quad N^{o} \quad$ 285/PGF/PG/FUNAI/2005. Disponível em <http://www.funai.gov.br >. Acesso em 23 ago. 2010.

<http://www.socioambiental.org > Acesso em 18 out. 2010 e 20 out. 2010 <http://funai.gov.br/ultimas/CNPI>. Acesso em 25 out. 2010. 